\title{
Review Article \\ Diversity of Mushrooms and Their Metabolites of Nutraceutical and Therapeutic Significance
}

\author{
Deepak K. Rahi and Deepika Malik \\ Department of Microbiology, Panjab University, Chandigarh 160014, India \\ Correspondence should be addressed to Deepak K. Rahi; deepakrahi10@rediffmail.com
}

Received 31 August 2015; Accepted 5 November 2015

Academic Editor: Praveen Rao Juvvadi

Copyright ( 2016 D. K. Rahi and D. Malik. This is an open access article distributed under the Creative Commons Attribution License, which permits unrestricted use, distribution, and reproduction in any medium, provided the original work is properly cited.

\begin{abstract}
Mushrooms are well known for their nutritional as well as therapeutic values worldwide. Interest in mushrooms has peaked because immunity and cellular protection are important issues for health conscious consumers and for those individuals who are dealing with serious health issues. Mushrooms generally belong to Basidiomycetes which harbors numerous mushroom species with diversity of metabolites of nutraceutical and therapeutic significance. They have been reported to be the most valuable ones for humans. Investigations on the therapeutic and nutritional properties of mushrooms are underway throughout the world. Researchers are providing crucial data on the array of bioactive compounds found within these fascinating fungi. People are now accepting mushrooms more as food and food supplements. Various academic and research institutes are all involved actively in research on bioactive metabolites of mushrooms. The present paper aims at reviewing the diversity of mushrooms and the types of metabolites especially of nutraceutical and therapeutic importance present in these mushrooms and their role as bioactive agents.
\end{abstract}

\section{Introduction}

Man has lived in a hunter-gatherer society for most of the time since their origin and has depended entirely on biodiversity for their sustenance. It is obvious that, during gathering forays, fruiting bodies of larger fungi, or macromycetes, were also collected and early man must have sampled anything of bitable nature. These fruiting bodies have been referred to as mushrooms or toadstools for many centuries. The word "truffle" has also been used in literature for some fruiting bodies of edible fungi, but these are characterized as growing below ground and must have been discovered subsequently in these gathering forays. Theophrastus $(300 \mathrm{BC})$ is the first writer to mention truffles and does so under several names. Since earliest times, mushrooms have been treated as a special kind of food. The Greeks believed that mushrooms provide strength for warriors in battle. The Pharaohs prized mushroom as delicacy, and the Romans regarded mushrooms as the "Food of the Gods," and they even had mushrooms on the menu which was served only on festive occasions. The Chinese treasured mushrooms as a health food. Mushrooms have probably been eaten for as long as people have walked the face of the Earth. These records concern wild mushrooms, but there are stories of mushrooms being cultivated in Asia as far back as the early middle ages. Mushrooms are the macrofungi with fleshy, subfleshy, or sometimes leathery, umbrellalike sporophores that bear their fertile surfaces either on lamellate or lining the tubes, opening out by means of pores. The lamellate members are commonly called "mushrooms" or "toadstool" depending upon whether they are edible or poisonous and the tube bearing or poroid members as "boletes" [1]. Diversity of mushrooms varies greatly ranging from the typical Agaricus mushrooms with a stalk and umbrella-shaped top to the polypores, Earth Stars (Geastrum), the Stink Horns (phalloides), and Puff Balls (Lycoperdon). Edible mushrooms are either collected from nature or more commonly cultivated and harvested under defined conditions with rigorous quality control on size, shape, tenderness, and palatability. Due to the high product yield and the low reproducibility costs from fungi, major interest has been shown in the respective markets for the metabolites derived from fungi. Both cellular components and secondary metabolites of large number of mushrooms have been shown to affect the immune system of host and 


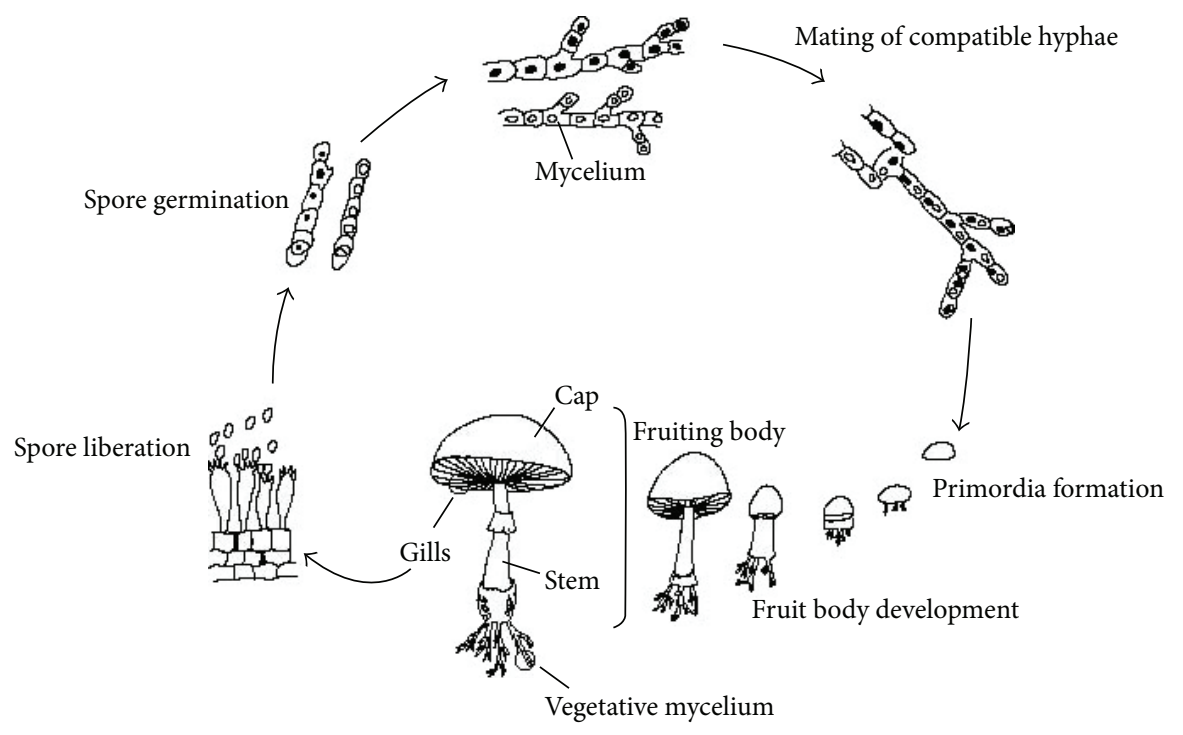

FIgURE 1: Life cycle of Agaricus bisporus [7].

therefore could be used to treat variety of diseases. Secondary metabolites are generally produced following active growth, and many have an unusual chemical structure. Interest in these compounds is considerable, as many natural products are of medical, industrial, and/or agricultural importance. Production of lipids, vitamins, and polysaccharides as well as intermediates in the synthesis of cell constituents such as amino acids and nucleotides are also of great economic importance in present-day industry [2-6].

Pure culture studies on mushrooms and related basidiomycetous fungi have laid the foundation for several biotechnological innovations including mass cultivation for diverse purposes. Strain improvement and selection among edible mushrooms like Agaricus, preparation of mushroom spawns and their application to composted natural substrates, and standardization of cultivation conditions to ensure proper mycelial colonization of the substrates to be followed by differentiation of the fruit bodies which are the commodities of commercial value are again well documented. Relatively less attention has been given to the nutrient value of edible mushroom mycelia cultivated in submerged culture. One of the pioneering efforts in this direction has been that of Humfeld and Sugihara in USA who patented mass cultivation of Agaricus mycelia in submerged cultures and explored their potential as protein feed supplements in animal and human nutrition. Whether the mycelium grown in submerged culture has the same flavor and nutritional aspects as that of the mushroom fruit bodies has been debated but because of the slow rate of growth of the mycelia in submerged culture and large volumes involved, the use of mushroom mycelia as feed supplements to enhance feed protein values in animal diets seems to be economically attractive. The basidiomycetes have some highly characteristic features, which separate them from other fungi. They are the most evolutionarily advanced fungi, and even their hyphae have a distinct "cellular" composition. Basidiomycetes produce basidiospores that are produced on a specialized structure called basidium. Although haploid, basidiospores may be either uninucleate or binucleate at maturity. After these basidiospores are released from mature fruiting bodies, they germinate to form hyphae. Collectively, hyphae make up mycelium. Hyphae derived from the spores of two different mating types then fuse to form secondary mycelium which has two nuclei and is ultimately responsible for the formation of fruiting bodies (Figure 1).

\section{Diversity of Mushrooms of Nutraceutical and Therapeutic Significance}

It has become increasingly apparent in recent years that the organisms traditionally referred to as fungi are not all closely related. This prompted some authors to use term "fungi" in a very general sense and the term "Fungi" with a capital "F" specifically for the so-called true fungi that appear to be related to one another. The true fungi are placed in the kingdom Fungi. Modern systematics, based on morphological characters and analysis of rDNA sequences, divides the kingdom Fungi into four major phyla or divisions: Chytridiomycota, Zygomycota, Ascomycota, and Basidiomycota. The two fungal phyla that produce large, visible fruit bodies are the Ascomycota and Basidiomycota. The Ascomycota contains at least 40,000 different species worldwide, many of them rather inconspicuous, but including such familiar groups as the morels and truffles, the cup fungi, and most of the lichens, as well as many microscopic molds and yeasts. They all produce their spores within macroscopic cells called asci, which typically open under pressure when mature, shooting the spores out into the air currents [8]. The Basidiomycota contains at least 30,000 different species worldwide and includes many of our most familiar fungi, including all the agarics (mushrooms and toadstools), puffballs and stinkhorns, bracket fungi, chanterelles, and club and coral fungi, as well as the plant-parasitic rusts and smuts [8]. All of them produce their spores on the external surface of 
microscopic cells called basidia and their fruit bodies have evolved in many ingenious ways in order to liberate these spores. The fungi comprising the phylum Basidiomycota commonly are known as basidiomycetes. Basidiomycota includes classes Hymenomycetes, Ustilaginomycetes, and Urediniomycetes. Hymenomycetes includes orders Agaricales, Aphyllophorales, Auriculariales, Dacrymycetales, Ceratobasidiales, and Tuslasnellales. Among Hymenomycetes, mainly the orders Agaricales, Aphyllophorales, and Auricularialesand class Gasteromycetes contain the mushrooms of pharmaceutical importance. The rest of the orders, that is, Dacrymycetales, Ceratobasidiales, and Tuslasnellales, contain parasitic and disease causing forms. Hymenomycetes also includes another subgroup (order) Tremellales. Ustilaginomycetes includes orders Ustilaginales and Exobasidiales which include smut causing forms, while Urediniomycetes include orders Uredinales, Septobasidiales, Sporidiales, and Eocronatirum that are responsible for causing rusts in various crop plants [9].

2.1. Order: Agaricales. The basidiomycetes include a large order Agaricales whose fruiting bodies are called mushrooms. Agaricales have been known to humans ever since we first became aware of our environment and are among the relatively few fungi that have common names in addition to scientific binomials: the death cup, Amanita phalloides; the shaggy mane, Coprinus comatus; the Jack-o'-lantern, Omphalotus olearius; and the honey mushroom, Armillaria mellea [9]. The fungi belonging to Agaricales probably have been studied to a great extent compared to members of any other order of Basidiomycota. As a group, agarics occur in a wide variety of habitats ranging from arctic to the tropics. While some species are known only from restricted areas, others exist in areas that are widely separated geographically. Even so, most species do seem to show preference for a certain type of natural habitat as well as for a particular substrate. They contain parasitic, saprobic, and mycorrhizal forms [9]. According to Chang [10], about 14 species of agarics are cultivated for food. Of these, only six are grown on industrial scale: enokitake or enoki mushroom, Flammulina velutipes; shiitake mushroom, Lentinula edodes; paddy straw mushroom, Volvariella volvacea; the oyster mushroom, Pleurotus ostreatus; and the meadow mushrooms, Agaricus brunnescens and $A$. bitorquis. Russulaceae is one of the most abundant and widely distributed ectomycorrhizal agaric families in the world [11, 12] containing three genera Russula, Lactarius, and Russulina (a synonym of Russula). Singer [11] reported 317 species of Russula and 122 species of Lactarius from all over the world. Two new tropical species each belonging to Russula and Lactarius have been reported from the forest region of Central India and were taxonomically described [13]. Table 1 describes the important mushroom species producing metabolites of nutraceutical and therapeutic relevance.

2.2. Order: Aphyllophorales. The order Aphyllophorales is another important group of Basidiomycota of about 1200 species. The order can be grouped as those Hymenomycetes that possess holobasidia but usually lack gills. The hymenia are borne on definite gymnocarpous basidiocarps; that is, the hymenium is exposed while the spores are still immature. The major importance of the species of Aphyllophorales as a whole is their saprobic activities as decomposers, particularly in degradation of cellulose and lignin. Although most species are saprobic in soil, litter, bark, and dead wood, some species may be truly parasitic or pathogenic on forest trees and nonwoody crops. The group also contains mycorrhizal forms associated with forest trees. A large number of species of Aphyllophorales have been used medicinally and many of them have been used in Indian folk medicines like Ganoderma lucidum, the fabled Ling Chi of Chinese herbal medicine [53]. Also known as Reishi, Ganoderma lucidum products often are advertised in natural food publications. They cure venereal disease and cancer and aid in purification of blood and lowering of cholesterol. About 12 species of Phellinus have been used in Indian folk medicine [54]. Antibiotics have been isolated from several of the Aphyllophorales, including a species of Phlebia [55]. A few species of aphyllophoralean fungi are edible, including the basidiocarps of the beef steak fungus (Fistulina hepatica); the bear's head fungus (Hericium erinaceum); and the sulphur fungus (Laetiporus sulphureus). Sclerotia of other species including Polyporus tuberaster also have been used as food [56]. The order Aphyllophorales is very large and heterogenous one. Table 2 describes the important genera and corresponding nutraceutical and therapeutic metabolite producing potential by the members of Aphyllophorales.

2.3. Order: Auriculariales. All species within the Auriculariales are thought to be saprotrophs; most of them are wood rotters. They are typically found on dead attached or fallen wood, though a few (Guepinia and Tremellodendropsis species) are normally found on the ground. As a group, their distribution is cosmopolitan. Many genera of order Auriculariales possess important nutritive and therapeutic values as shown in Table 3.

2.4. Gasteromycetes. Gasteromycetes, the "stomach fungi," a polyphyletic assemblage of basidiomycetous fungi, are characterized by the fact that their basidiospores mature inside the basidiocarps and are not discharged forcibly from the basidia. They include puffballs, earthstars, stinkhorns, and bird's nest fungi. Although their basidiocarps vary in appearance, they all possess a distinct outer covering or wall termed the peridium. This covering may vary from almost paper thin in some taxa to thick and rubbery or even hard in others and may open naturally in various ways after the spores are mature or remain closed permanently, with the spores liberated only after the disintegration of the peridium through the action of external agents. Depending upon the species, the glebal tissue, that is, the fertile portion of the basidiocarp enclosed by peridium, may be monomitic, consisting of only thin walled, generative hyphae, or dimitic, consisting of both generative and skeletal hyphae. Most Gasteromycetes are either saprobes or mycorrhizal fungi. Although most are terrestrial forms, species of the genus $\mathrm{Nia}$ are wood rotters in marine habitats [69]. Table 4 summarizes the important genera producing metabolites of nutraceutical and therapeutic importance. 
TABLE 1: Diversity of nutraceutical and therapeutic metabolite producing mushrooms found in order Agaricales (nomenclature source: Mycobank).

\begin{tabular}{|c|c|c|c|}
\hline Family & Important genera & Therapeutic/nutritional value & References \\
\hline Hygrophoraceae & Hygrophorus & $\begin{array}{l}\text { Fatty acids with bactericidal and fungicidal activity prepared from } \\
\text { Hygrophorus eburneus. Hygrophamides are important constituents of } \\
\text { cell membranes and assumed to play important roles as antigens and } \\
\text { their receptors. }\end{array}$ & {$[9,14]$} \\
\hline Tricholomataceae & $\begin{array}{l}\text { Clitocybe, } \\
\text { Tricholoma }\end{array}$ & $\begin{array}{l}\text { Tricholoma magnivelare, the pine mushroom, or the white matsutake, is } \\
\text { another edible mushroom known to enhance fertility and virility, } \\
\text { strengthen the immune system, have anticancer activity, and even work } \\
\text { as an aphrodisiac. }\end{array}$ & {$[9]$} \\
\hline Amanitaceae & Amanita & $\begin{array}{l}\text { A. phalloides, also known as "death cup," is a well-known poisonous } \\
\text { mushroom of this genus and is also reported to be used in tumor therapy. }\end{array}$ & {$[9,15]$} \\
\hline Agaricaceae & Agaricus & $\begin{array}{l}\text { A. campestris and A. rodmani are edible. A. brunnescens (bisporus) is } \\
\text { grown commercially. }\end{array}$ & {$[9]$} \\
\hline Strophariaceae & $\begin{array}{l}\text { Stropharia, } \\
\text { Naematoloma, } \\
\text { Psilocybe }\end{array}$ & $\begin{array}{l}\text { The well-known edible members of the genus Stropharia include } \\
\text { Stropharia rugosoannulata and Stropharia aeruginosa. These mushrooms } \\
\text { are a low calorie and fat-free food choice, known to assist in weight loss. } \\
\text { Psilocybe cubensis's principal active compounds are psilocybin and } \\
\text { psilocin which have mind-altering effects like euphoria and visual and } \\
\text { mental hallucinations. }\end{array}$ & {$[9,11]$} \\
\hline Coprinaceae & Coprinus Panaeolus & $\begin{array}{l}\text { Coprinus atramentarius is edible unless consumed with alcohol. } \\
\text { Coprinus comatus has antioxidant properties. }\end{array}$ & {$[9]$} \\
\hline Pluteaceae & Pluteus Volvariella & P. cervinus, $P$. atromarginatus, and $V$. volvacea all are edible. & [9] \\
\hline Cortinariaceae & $\begin{array}{l}\text { Cortinarius } \\
\text { Galerina }\end{array}$ & Cortinarius sp. is inedible and some are poisonous too. & {$[16]$} \\
\hline Psathyrellaceae & Psathyrella & $\begin{array}{l}\text { Psathyrella atroumbonata Pegler is one of the most valuable edible } \\
\text { mushrooms in Nigeria as it is very rich in protein and fibres. }\end{array}$ & {$[17]$} \\
\hline Inocybaceae & Inocybe & $\begin{array}{l}\text { Inocybe aeruginascens contains the formerly known alkaloids psilocybin, } \\
\text { psilocin, baeocystin, and aeruginascin. }\end{array}$ & {$[16]$} \\
\hline Strophariaceae & Pholiota & $\begin{array}{l}\text { Polysaccharide isolated from Pholiota nameko (PNPS-1) led to significant } \\
\text { decreases in very low-density lipoprotein/low-density lipoprotein } \\
\text { cholesterol and an increase in high-density lipoprotein cholesterol. } \\
\text { A novel lectin from Pholiota adiposa showed antiproliferative activity. }\end{array}$ & {$[18,19]$} \\
\hline Marasmiaceae & $\begin{array}{l}\text { Marasmius, } \\
\text { Omphalotus }\end{array}$ & $\begin{array}{l}\text { Marasmius oreades, the fairy ring } \\
\text { mushroom, is a good edible species containing } \\
\mathrm{Cu}, \mathrm{Fe}, \mathrm{Zn} \text {, folic acid, protein, and all the essential amino acids required } \\
\text { by man. }\end{array}$ & [9] \\
\hline Omphalotaceae & Lentinula & $\begin{array}{l}\text { Lentinula edodes is low in sodium and glucose, rich source of fibre, and } \\
\text { ideal for diabetics. In Japan, it is used as a natural treatment of cancer } \\
\text { because of its complex carbohydrate, lentinan. It is also a source of } \\
\text { selenium, an antioxidant that is said to prevent cancer. }\end{array}$ & [9] \\
\hline Lyophyllaceae & Termitomyces & $\begin{array}{l}\text { Methanolic extract of Termitomyces albuminosus mycelia showed high } \\
\text { antioxidant properties. } \\
\text { Polysaccharide-rich fraction of Termitomyces eurhizus accelerates } \\
\text { healing of indomethacin induced gastric ulcer. } \\
\text { Analgesic and anti-inflammatory effects of the dry matter of culture } \\
\text { broth of Termitomyces albuminosus and its extracts. }\end{array}$ & {$[20-22]$} \\
\hline Pleurotaceae & Pleurotus & $\begin{array}{l}\text { Ribonucleases (RNases: mol. wt. } 10.7 \mathrm{kDa} \text { ) have been isolated and } \\
\text { characterized from P. ostreatus that has the potentiality to neutralize } \\
\text { HIV through degradation of viral genetic material. }\end{array}$ & {$[23]$} \\
\hline Hydnangiaceae & Laccaria & $\begin{array}{l}\text { Laccaria edulis, Laccaria laccata, and Laccaria proxima are all edible } \\
\text { species. }\end{array}$ & {$[24]$} \\
\hline Physalacriaceae & $\begin{array}{l}\text { Flammulina } \\
\text { Armillaria }\end{array}$ & $\begin{array}{l}\text { Flammulina velutipes is rich in peroxidase, superoxide dismutase, and } \\
\text { others and can prevent some severe diseases like cancer and coronary } \\
\text { heart disease. }\end{array}$ & {$[25]$} \\
\hline
\end{tabular}


TABLE 2: Diversity of nutraceutical and therapeutic metabolite producing mushrooms found in order Aphyllophorales.

\begin{tabular}{|c|c|c|c|c|c|}
\hline Family & $\begin{array}{l}\text { Important } \\
\text { genera }\end{array}$ & Therapeutic properties & Bioactive components & Mode of action & References \\
\hline \multirow[t]{2}{*}{ Hymenochaetaceae } & \multirow[t]{2}{*}{$\begin{array}{l}\text { Inonotus } \\
\text { Phellinus }\end{array}$} & $\begin{array}{l}\text { I. obliquus (chaga } \\
\text { mushroom) is used for } \\
\text { cancer, gastritis, ulcer and } \\
\text { tuberculosis of bones, } \\
\text { treatment of breast, liver, } \\
\text { uterine, and gastric cancer, } \\
\text { hypertension, and diabetes. }\end{array}$ & $\begin{array}{l}\text { Phenolic compounds, } \\
\text { melanin and lanostane-type } \\
\text { terpenoids, and betulinic } \\
\text { acid (pentacyclic } \\
\text { triterpenoids) }\end{array}$ & \multirow[t]{2}{*}{$\begin{array}{l}\text { Stimulates body to } \\
\text { produce natural killer } \\
\text { cells to battle infection } \\
\text { and tumor growth }\end{array}$} & \multirow[t]{2}{*}{$\begin{array}{l}\text { M. Blackwell, } \\
\text { "unpublished } \\
\text { data,", } 1994\end{array}$} \\
\hline & & $\begin{array}{l}\text { I. dryadeus possess } \\
\text { antibacterial activity. }\end{array}$ & $\begin{array}{l}\text { Nonlinear, complex (1-3) } \\
\text { and (1-6) } \beta \text {-D-glucans, a } \\
\text { type of polysaccharide }\end{array}$ & & \\
\hline \multirow[t]{2}{*}{ Ganodermataceae } & \multirow[t]{2}{*}{ Ganoderma } & $\begin{array}{l}\text { Ganoderma lucidum (also } \\
\text { known as Reishi) shows } \\
\text { antitumor, } \\
\text { immune-modulating } \\
\text { activities for treatment of } \\
\text { hypoglycemosis, } \\
\text { hepatoprotection, and the } \\
\text { effect on blood vessel } \\
\text { system. This mushroom has } \\
\text { been used in traditional } \\
\text { Chinese and Japanese } \\
\text { medicines. } \\
\text { Reishi is commonly } \\
\text { prescribed for a host of } \\
\text { conditions such as anxiety, } \\
\text { high blood pressure, } \\
\text { bronchitis, insomnia, and } \\
\text { asthma but is particularly } \\
\text { renowned for its use in } \\
\text { hepatitis and other diseases } \\
\text { of liver. It also prevents } \\
\text { "fatty-liver" and cirrhosis } \\
\text { due to alcohol abuse. }\end{array}$ & $\begin{array}{l}\text { Mucopolysaccharides and } \\
\text { polysaccharide-protein } \\
\text { complexes }\end{array}$ & \multirow[t]{2}{*}{$\begin{array}{l}\text { Activates the immune } \\
\text { response of the host and } \\
\text { leads to the induction of } \\
\text { cell differentiation and } \\
\text { metabolizing enzymes, } \\
\text { the inhibition of } \\
\text { angiogenesis, and the } \\
\text { expression of the } \\
\text { urokinase-type } \\
\text { plasminogen activator } \\
\text { (uPA) and the uPA } \\
\text { receptor in cancer cells }\end{array}$} & \multirow[t]{2}{*}[26]{} \\
\hline & & $\begin{array}{l}\text { Ganoderma applanatum } \\
\text { have been reported to show } \\
\text { immunostimulating } \\
\text { properties, fight cancer, } \\
\text { stop pain, eliminate } \\
\text { indigestion, and reduce } \\
\text { phlegm, antibiotic and } \\
\text { antiviral. }\end{array}$ & $\begin{array}{l}\beta \text {-D-glucans and their } \\
\text { protein complexes, for } \\
\text { example, xyloglucans and } \\
\text { acidic } \beta \text {-D-glucan } \\
\text { containing uronic acid, } \\
\text { dietary fibres, lectins, and } \\
\text { terpenoids }\end{array}$ & & \\
\hline Cantharellaceae & Cantharellus & $\begin{array}{l}\text { The edible species } C \text {. } \\
\text { cibarius, commonly known } \\
\text { as chanterelles, have } \\
\text { antimicrobial activity } \\
\text { against some Gram positive } \\
\text { and Gram negative } \\
\text { bacteria, yeasts, filamentous } \\
\text { fungi, and actinomycetes. } \\
\text { They are also known for } \\
\text { their antitumor, antioxidant } \\
\text { activity and antigenotoxic } \\
\text { potential. }\end{array}$ & $\begin{array}{l}\text { Ethyl alcohol, chloroform, } \\
\text { and ethanol }\end{array}$ & & {$[27,28]$} \\
\hline
\end{tabular}


TABLE 2: Continued.

\begin{tabular}{|c|c|c|c|c|c|}
\hline Family & $\begin{array}{l}\text { Important } \\
\text { genera }\end{array}$ & Therapeutic properties & Bioactive components & Mode of action & References \\
\hline Schizophyllaceae & Schizophyllum & $\begin{array}{l}\text { Pharmacologically, } S \text {. } \\
\text { commune is very important } \\
\text { because it produces } \\
\text { polysaccharide which } \\
\text { shows anticancer activity in } \\
\text { xenography and clinical } \\
\text { practice. }\end{array}$ & Schizophyllan ( $\beta$-D-glucan) & Immunomodulation & {$[29]$} \\
\hline Sparassidaceae & Sparassis & $\begin{array}{l}\text { Sparassis crispa (cauliflower } \\
\text { fungus), its fruiting bodies } \\
\text { have antitumor properties } \\
\text { and also contain chemicals } \\
\text { which may stimulate } \\
\text { immune system and inhibit } \\
\text { growth of superbug MRSA } \\
\text { (methicillin-resistant } \\
\text { Staphylococcus aureus). }\end{array}$ & $\begin{array}{l}\text { Bioactive } \beta \text {-D-glucan, } \\
\text { phenyl derivatives, } \\
\text { chalcones, and } \\
\text { sesquiterpenoids }\end{array}$ & $\begin{array}{l}\text { Exhibits various } \\
\text { biological activities, } \\
\text { including enhancement } \\
\text { of the hematopoietic } \\
\text { response and induction } \\
\text { of cytokine production }\end{array}$ & {$[30,31]$} \\
\hline Polyporaceae & Polyporus & $\begin{array}{l}\text { Polyporus umbellatus have } \\
\text { anticancer and diuretic } \\
\text { properties. From Polyporus } \\
\text { alveolaris, a polypeptide } \\
\text { with antifungal properties } \\
\text { has been isolated from the } \\
\text { fresh fruit bodies of this } \\
\text { species named alveolarin. }\end{array}$ & $\begin{array}{l}\text { Nucleotides, nucleosides, } \\
\text { proteins, amino acids, } \\
\text { vitamins, polysaccharides, } \\
\text { and triterpenoids }\end{array}$ & $\begin{array}{l}\text { Their diuretic property } \\
\text { has been used to get rid } \\
\text { of the toxins that are } \\
\text { responsible for causing } \\
\text { infections in the urinary } \\
\text { tract and is also found to } \\
\text { be very effective against } \\
\text { urethral blockages }\end{array}$ & {$[32]$} \\
\hline
\end{tabular}

TABLE 3: Diversity of nutraceutical and therapeutic metabolite producing mushrooms found in order Auriculariales.

\begin{tabular}{|c|c|c|c|c|}
\hline Family & Important genera & $\begin{array}{c}\text { Therapeutic/nutritional } \\
\text { value }\end{array}$ & Bioactive component & References \\
\hline Auriculariaceae & $\begin{array}{l}\text { Auricularia } \\
\text { Exidia } \\
\text { Exidiopsis } \\
\text { Eichleriella } \\
\text { Fibulosebacea } \\
\text { Heterochaete } \\
\text { Pseudostypella }\end{array}$ & $\begin{array}{l}\text { Auricularia auricula-judae } \\
\text { and A. cornea are cultivated } \\
\text { on a commercial scale, } \\
\text { particularly in China and } \\
\text { south East Asia. }\end{array}$ & $\begin{array}{l}\text { The acidic heteroglycans isolated } \\
\text { from Auricularia auricula-judae } \\
\text { exhibit antitumor activity }\end{array}$ & {$[33,34]$} \\
\hline Hyaloriaceae & $\begin{array}{l}\text { Helicomyxa } \\
\text { Hyaloria } \\
\text { Myxarium }\end{array}$ & - & - & [9] \\
\hline
\end{tabular}

\section{Nutraceutical Metabolites of Mushrooms}

It is understood that human beings have constantly been in search of new substances that can improve biological functions and make people fitter and healthier. Recently, the society has turned towards plants, herbs, and food as sources of these enhancers. These products have been called variously vitamins, dietary supplements, functional foods, nutraceuticals, nutraceuticals, and so forth [70-72]. Mushrooms, in this regard, are now beginning to receive much deserved attention for their very real health giving qualities. It is their flavor and texture for which they have long been devoured by the mankind. Scientific appreciation of their nutritional and medicinal attributes is a recent phenomenon. Mushrooms are perhaps the only fungi deliberately and knowingly consumed by human beings and they complement and supplement the human diet with various ingredients not encountered or deficient in food items of plants and animal origin. Besides, unique chemical composition makes them suitable for specific groups suffering with certain physiological disorders or ailments. This makes the mushrooms an ultimate health food.

The term "nutraceutical" was coined in 1979 by Stephen Deflice, founder and chairman of the foundation for Innovation in Medicine located at Cranford, New Jersey. The word "nutra" derived from nutrition and "ceutical" from pharmaceutical refers to substances that may be considered a food or part of a food and may provide health benefits. It was defined as a food or part of food that provides medical or health benefits, including the prevention and treatment of diseases [73]. Nutraceuticals may range from isolated nutrients, herbal products, dietary supplements, nutraceuticals, and diets to genetically engineered designer foods and processed products such as cereals, soups, and beverages. Doubtlessly, many of these products possess pertinent 
TABLE 4: Diversity of nutraceutical and therapeutic metabolite producing mushrooms found in class Gasteromycetes.

\begin{tabular}{|c|c|c|c|c|}
\hline Order & Family & $\begin{array}{l}\text { Important } \\
\text { genera }\end{array}$ & Therapeutic/nutritional value & References \\
\hline Lycoperdales & $\begin{array}{l}\text { Lycoperdaceae } \\
\text { Geastraceae }\end{array}$ & $\begin{array}{l}\text { Calvatia } \\
\text { Lycoperdon } \\
\text { Radiigera } \\
\text { Geastrum }\end{array}$ & $\begin{array}{l}\text { Calvatia gigantea and Calvatia } \\
\text { caelata are used in burnt cases due } \\
\text { to their anesthetic nature. } \\
\text { Calvatia spp. are also used to stop } \\
\text { bleeding from wounds. } \\
\text { Calvacin isolated from Calvatia } \\
\text { gigantea having antitumor activity. } \\
\text { Lycoperdon pusillum is used to cure } \\
\text { sores, abrasion or bruises, deep cut, } \\
\text { hemorrhages, and urinary } \\
\text { infections. }\end{array}$ & {$[35-37]$} \\
\hline Tulostomatales & $\begin{array}{l}\text { Calostomataceae } \\
\text { Tulostomataceae }\end{array}$ & $\begin{array}{l}\text { Calostoma } \\
\text { Tulostoma } \\
\text { Battarrea }\end{array}$ & $\begin{array}{l}\text { Calostoma cinnabarina has been } \\
\text { recorded to be an edible mushroom. } \\
\text { Antibacterial activity has been } \\
\text { reported in Tulostoma obesum. }\end{array}$ & {$[38,39]$} \\
\hline Sclerodermatales & & $\begin{array}{l}\text { Scleroderma } \\
\text { Astraeus } \\
\text { Pisolithus }\end{array}$ & $\begin{array}{l}\text { Polysaccharide from Astraeus } \\
\text { hygrometricus has been reported for } \\
\text { macrophage stimulation. }\end{array}$ & {$[40]$} \\
\hline Phallales & $\begin{array}{l}\text { Phallaceae } \\
\text { Clathraceae }\end{array}$ & $\begin{array}{l}\text { Mutinus } \\
\text { Pseudocolus } \\
\text { Linderia }\end{array}$ & 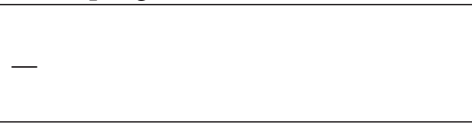 & [9] \\
\hline Nidulariales & $\begin{array}{l}\text { Nidulariaceae } \\
\text { Sphaerobolaceae }\end{array}$ & $\begin{array}{l}\text { Nidularia } \\
\text { Sphaerobolus }\end{array}$ & - & [9] \\
\hline
\end{tabular}

physiological functions and valuable biological activities [74]. A regular intake may enhance the immune response of the human body thereby increasing resistance to disease and in some cases causes regression of a disease state. The Dietary Supplement Health and Education Act of 1994 expanded the definition of nutraceuticals to include vitamins, minerals, herbs, botanicals, amino acids, and any dietary substances used by humans to fortify the diet by increasing total dietary intake $[75,76]$. The term "mushroom nutraceuticals" has been coined by Chang and Buswell [77] to describe those compounds that have considerable potential as dietary supplements, used for the enhancement of health and prevention of various human diseases. The important edible mushrooms with remarkable nutraceuticals properties include the species of Lentinus (Lentinula), Auricularia, Hericium, Grifola, Flammulina, Pleurotus, Lactarius, Pisolithus, Tremella, Russula, Agaricus, Cordyceps, and so forth. A mushroom nutraceutical is refined/partially defined extractives from either mycelium or fruiting bodies, which is consumed in form of capsule or tablet as dietary supplement (not as regular food).

The mushrooms are now recognized as a source of nutraceuticals in nutrient balancing, strengthening human immune system, enhancing natural body resistance, and lowering proneness to disease [1]. Since most nutraceuticals are extracted from edible mushroom species, there is a little scope of toxicity and overdose. The nutritional value of mushrooms is greater than one may think. More than just a condiment for salads, they are actually one of the healthier foods that one can eat. Mushrooms besides being culinary delicacies are also known for their nutritional and medicinal values, a fact which has also been supported by many recent studies. Thus, mushrooms have started getting much deserved attention for their very real nutraceutical values. Mushrooms are consumed for their palatability and/or nutritional value. Palatability can be judged by color, texture, flavor, and taste, but the determination of nutritional value requires scientific work. It involves the analysis of proximate composition and a study of spectrum of amino acids, fatty acids, vitamins, minerals, nucleic acid, and so forth. It should be noted that the composition of a given species is affected by the diversity of its genetic make-up that leads to strain differences and by environmental conditions, including the nature of substratum. Mushrooms have good flavor, texture, and also all essential amino acids for humans, including lysine and methionine which are commonly deficient in plants [78]. The nutritional value of edible mushrooms nearly equals that of milk and meat. They contain high amount of essential amino acids (lysine, valine, and leucine), proteins, carbohydrates, vitamins, unsaturated fatty acids, fibers, and minerals. Mushrooms are very low in calorie, fat, and sodium. Mushrooms are also cholesterol-free.

Most mushrooms have high protein content, usually around $20-30 \%$ by dry weight. This can be useful for vegetarians or anyone looking to increase the protein content in their diet. Fiber helps to lower cholesterol and is important for the digestive system. Niacin and other important B vitamins are found in many edible mushrooms. As certain B vitamins are found in animal tissue but not plants, this can be another good supplement for vegetarians. Vitamin D is also present which is essential for the absorption of calcium. Fruiting bodies, in general, on dry weight basis, contain about $55 \%$ carbohydrate, $32 \%$ protein, and $2 \%$ fat, and the rest is ash 
TABLE 5: Proximate composition of cultivated species of edible mushrooms.

\begin{tabular}{|c|c|c|c|c|c|c|c|c|}
\hline Species & Moisture & $\begin{array}{l}\text { Crude } \\
\text { protein }\end{array}$ & $\begin{array}{c}\text { Crude } \\
\text { fat }\end{array}$ & Carbohydrates & Crude fiber & Ash & Energy & References \\
\hline Agaricus bisporus & $78.3-90.5$ & $23.9-34.8$ & $1.7-8.0$ & $51.3-62.5$ & $8.0-10.4$ & $7.7-12.0$ & $328-368$ & {$[41]$} \\
\hline Agaricus campestris & 89.7 & 33.2 & 1.9 & 56.9 & 8.1 & 8.0 & 354 & {$[41]$} \\
\hline Boletus edulis & 87.3 & 29.7 & 3.1 & 59.7 & 8.0 & 7.5 & 362 & {$[41]$} \\
\hline Flammulina velutipes & 89.2 & 17.6 & 1.9 & 73.1 & 3.7 & 7.4 & 378 & {$[41]$} \\
\hline Lentinus edodes & $90-91.8$ & $13.4-17.5$ & $4.9-8.0$ & $67.5-78.0$ & $7.3-8.0$ & $3.7-7.0$ & $387-392$ & {$[41]$} \\
\hline Pleurotus ostreatus & $73.7-90.8$ & $10.5-30.4$ & $1.6-2.2$ & $57.6-81.8$ & $7.5-8.7$ & $6.1-9.8$ & $345-367$ & {$[41]$} \\
\hline Pleurotus sajor-caju & 90.1 & 26.6 & 2.0 & 50.7 & 13.3 & 6.5 & 300 & {$[42]$} \\
\hline Volvariella volvacea & 89.1 & 25.9 & 2.4 & - & 9.3 & 8.8 & 276 & {$[43]$} \\
\hline Russula vesca & - & 22.8 & 0.1 & 71 & - & - & - & {$[44]$} \\
\hline Lactarius trivialis & 37 & - & 0.1 & 64 & - & - & - & {$[44]$} \\
\hline Lentinus tigrinus & 6 & - & 0.1 & 62 & - & - & - & {$[44]$} \\
\hline Agaricus arvensis & 94.9 & 2.87 & 0.14 & 1.91 & - & 0.18 & 20.38 & {$[45]$} \\
\hline Lactarius deliciosus & 90 & 2.96 & 0.22 & 6.26 & - & 0.51 & 38.86 & {$[45]$} \\
\hline Leucopaxillus giganteus & 92.43 & 3.4 & 0.41 & 3.11 & - & 0.65 & 29.73 & {$[45]$} \\
\hline Stegastes imbricatus & 93.89 & 2.35 & 0.09 & 3.38 & - & 0.29 & 23.73 & {$[45]$} \\
\hline Tricholoma portentosum & 93.05 & 2.12 & 0.38 & 3.64 & - & 0.81 & 26.46 & {$[45]$} \\
\hline Cantharellus cibarius & - & 26.25 & 9.14 & 18 & 13.64 & 25.78 & - & {$[46]$} \\
\hline Clitocybe odora & - & 41.13 & 14.29 & 11.50 & 12.72 & 17.44 & - & {$[46]$} \\
\hline Laccaria laccata & - & 14.03 & 8.48 & 8.17 & 10.96 & 33.60 & - & {$[46]$} \\
\hline Auricularia polytricha & 95.6 & 8.5 & 5.2 & 5.9 & 3.5 & 5.2 & - & {$[47]$} \\
\hline Lentinus subnudus & 90.3 & 5.1 & 4.5 & 8.9 & 6.5 & 7.1 & - & {$[47]$} \\
\hline Morchella esculenta & 94.5 & 25.4 & 10.8 & 8.9 & 8.3 & 10.8 & - & {$[47]$} \\
\hline Pleurotus ostreatus & 4.46 & 20.82 & 0.56 & 68.35 & 45.5 & 5.81 & - & {$[47]$} \\
\hline Pleurotus sajor-caju & 5.32 & 21.30 & 0.29 & 65.14 & 42.5 & 7.95 & - & {$[47]$} \\
\hline
\end{tabular}

Note: all data are presented as percentage of dry weight except moisture (percentage of fresh weight) and energy value (Kcal per $100 \mathrm{~g}$ dry weight).

constituting the minerals [41]. Therefore, the commercial cultivation of these mushrooms is steadily increasing to exploit their metabolic products for human health. Mushrooms are also blessed with a variety of hydrolyzing and oxidizing enzymes [79]. Table 5 summarizes the general proximate composition of different nutrients found in various edible species of mushrooms.

3.1. Proteins. The protein content of four popular edible mushrooms, Agaricus bisporus, Lentinus edodes, Pleurotus spp., and Volvariella volvacea, which are cultivated in various countries, ranges from 1.75 to $3.63 \%$ of their fresh weight [80]. The value can be as high as 5.9\%; however, an average value of 3.5 to $4 \%$ would appear to be representative. This shows that the protein content of edible mushrooms, in general, is about twice that of asparagus and cabbage and 4 times and 12 times those of oranges and apples, respectively. On dry weight basis, mushrooms normally contain 19 to $35 \%$ protein, as compared to $7.3 \%$ in rice, $13.2 \%$ in wheat, $39.1 \%$ in soybean, and $25.2 \%$ in milk. Therefore, in amount of crude protein, mushrooms rank below most animal meats but well above most other foods, including milk [81]. This can be useful for vegetarians or anyone looking to increase the protein content in their diet. Pleurotus sajor-caju (1.60 g/100 g), Morchella esculenta
(1.62 g/100 g), Pleurotus ostreatus (1.68 g/100 g), Agaricus bisporus $(1.80 \mathrm{~g} / 100 \mathrm{~g})$, and Boletus edulis (2.20 g/100 g) are also a good source of protein [82].

3.2. Essential Amino Acids. Since proteins are made up from 20 amino acids in varying amounts, they are quantitatively different. There are nine amino acids that are not synthesized within the body. These are called essential amino acids (lysine, methionine, tryptophan, threonine, valine, leucine, isoleucine, histidine, and phenylalanine). The proteins of commonly cultivated mushrooms contain all nine amino acids essential for man. The most abundant essential amino acid turns out to be lysine and the lowest levels among the essential amino acids are tryptophan and methionine as mentioned in Table 6.

3.3. Fat. The fat content in different species of mushrooms ranges from 1.1 to $8.3 \%$ on dry weight basis. Thus, an average value of $4 \%$ would appear to be representative (Table 7 ). In general, the crude fat of mushrooms represents all classes of lipid compounds including free fatty acids, monoglycerides, diglycerides, triglycerides, sterols, sterol esters, and phospholipids. At least, $72 \%$ of the total fatty acids were found to be unsaturated in each one of these mushrooms, thus making 
TABLE 6: Essential amino acid (EAA) composition of some important edible mushrooms.

\begin{tabular}{|c|c|c|c|c|c|c|c|c|c|}
\hline Mushroom species & Valine & Leucine & Isoleucine & Threonine & Methionine & Lysine & Phenylalanine & Tryptophan & References \\
\hline Agaricus bisporus & 2.5 & 7.5 & 4.5 & 5.5 & 0.9 & 9.1 & 4.2 & 2.0 & [48] \\
\hline Lentinus edodes & 3.7 & 7.9 & 4.9 & 5.9 & 1.9 & 3.9 & 5.9 & $\mathrm{Nd}$ & {$[48]$} \\
\hline Pleurotus florida & 6.9 & 7.5 & 5.2 & 6.1 & 3.0 & 9.9 & 3.5 & 1.1 & {$[48]$} \\
\hline Volvariella diplasia & 9.7 & 5.0 & 7.8 & 6.0 & 1.2 & 6.1 & 7.0 & 1.5 & {$[48]$} \\
\hline Volvariella volvacea & 5.4 & 4.5 & 3.4 & 3.5 & 1.1 & 7.1 & 2.6 & 1.5 & {$[48]$} \\
\hline Cantharellus cibarius & 3.5 & 16.3 & 3.3 & 4.2 & 1.0 & 4.3 & 3.2 & 1.7 & [49] \\
\hline Tricholoma portentosum & 7.8 & 9.4 & 3.7 & 9.5 & 3.0 & 8.6 & 4.4 & 1.0 & {$[50]$} \\
\hline Tricholoma terreum & 8.9 & 8.2 & 3.6 & 9.1 & 3.5 & 7.6 & 6.6 & 1.1 & {$[50]$} \\
\hline Pleurotus ostreatus & 0.91 & 1.13 & 0.62 & 1.10 & 0.28 & 0.71 & 0.73 & 0.15 & {$[51]$} \\
\hline Pleurotus sajor-caju & 0.98 & 1.3 & 0.75 & 0.98 & 0.34 & 0.78 & 0.86 & 0.09 & {$[51]$} \\
\hline${ }^{*}$ Lactarius quieticolor & 41.9 & 4611 & 71.7 & 80.2 & 67.2 & 24.6 & 0.1 & - & {$[52]$} \\
\hline${ }^{*}$ Gomphus floccosus & 10.5 & 22.7 & 5.0 & 17.7 & 57.2 & 14.3 & 0.2 & - & {$[52]$} \\
\hline${ }^{*}$ Ramaria brevispora & 16.3 & 22.3 & 0.2 & 24.6 & 16.2 & 39.8 & 5.4 & - & {$[52]$} \\
\hline${ }^{*}$ Coprinopsis cinerea & 0.5 & 248 & 0 & 21 & 0.6 & 1.4 & 0 & - & {$[52]$} \\
\hline
\end{tabular}

Note: data presented as grams of amino acid per 100 grams of sample.

${ }^{*}$ Values are expressed on dry weight basis ( $\mu \mathrm{g} / 100$ grams of sample).

$\mathrm{Nd}=$ not determined.

TABLE 7: The total lipids in some important edible mushrooms [57].

\begin{tabular}{lc}
\hline Mushroom & Percent of lipids in dry weight \\
\hline Volvariella volvacea & 3.0 \\
Lentinus edodes & 2.1 \\
Agaricus bisporus & 3.1 \\
Pleurotus sajor-caju & 1.6 \\
Auricularia auricular & 1.3 \\
Tremella fuciformis & 0.6 \\
Morchella esculenta & $1.96(\mathrm{~g} / 100 \mathrm{mg})$ \\
Pleurotus ostreatus & $2.2(\mathrm{~g} / 100 \mathrm{mg})$ \\
Boletus edulis & $3.6(\mathrm{~g} / 100 \mathrm{mg})$ \\
\hline
\end{tabular}

mushrooms a health food as they are essential in our diet, whereas saturated fatty acids may be harmful to our health [83].

3.4. Vitamins. Mushrooms have been reported to be good source for several vitamins. The B-group vitamins are abundant [77, 84-88] mainly thiamine (vitamin B1), riboflavin (vitamin B2), niacin, biotin, and other vitamins like ascorbic acid (vitamin C) [41]. The thiamine content ranges from $0.35 \mathrm{mg}$ in Volvariella volvacea to $1.14 \mathrm{mg}$ in Agaricus bisporus, to 1.16 and to $4.80 \mathrm{mg}$ in Pleurotus spp., and to $7.8 \mathrm{mg}$ in $L$. edodes (mg per $100 \mathrm{~g}$ dry weight of mushroom). The niacin content varies from $54.9 \mathrm{mg}$ in L. edodes to $55.7 \mathrm{mg}$ in $A$. bisporus, to $64.88 \mathrm{mg}$ in $V$. volvacea, and to 46.0 and to $108.7 \mathrm{mg}$ in Pleurotus spp. The riboflavin content is higher in A. bisporus $(5.0 \mathrm{mg}$ ) and L. edodes $(4.9 \mathrm{mg}$ ) than in $V$. volvacea (1.63 to $2.98 \mathrm{mg})$. Vitamin $\mathrm{C}$ content has been reported to be highest in L. edodes ( $9.4 \mathrm{mg} / 100 \mathrm{~g}$ dry sample) followed by $P$. sajor-caju, A. bisporus, and $V$. volvacea with $7.4 \mathrm{mg}, 1.8 \mathrm{mg}$, and $1.4 \mathrm{mg}$ [81].

3.5. Carbohydrate. According to [41], pentoses, methylpentoses, hexoses, disaccharides, amino sugars, sugar alcohols, and sugar acids are constituents of mushroom carbohydrates. Pleurotus species contain carbohydrates ranging from 46.6 to $81.8 \%$ as compared to $60 \%$ in $A$. bisporus on dry weight basis. The fiber content ranges from 7.4 to $27.6 \%$ in Pleurotus species as compared to $10.4 \%$ in A. bisporus and 4 to $20 \%$ in V. volvacea.

3.6. Fiber. Fiber is considered to be an important ingredient in a balanced diet. Feeding diabetic patients with high fiber diets reduces their daily insulin requirement and stabilizes their blood glucose profile, possibly by decreasing the rate of glucose absorption [89]. High molecular weight materials excreted without digestion and absorption by humans are called dietary fiber [90]. Most of the active polysaccharides, water soluble or insoluble, isolated from mushrooms can be classified as dietary fibers. Mushrooms contain 10-50\% dietary fibers in dried matter.

3.7. Minerals. Mushrooms are a good source of minerals. It is calculated that the concentrations of $\mathrm{K}, \mathrm{P}, \mathrm{Na}, \mathrm{Ca}$, and $\mathrm{Mg}$ constitute about 56 to $70 \%$ of the total ash content [63]. Potassium is particularly abundant and accounts for nearly $45 \%$ of the total ash content. It is an extremely important mineral that regulates blood pressure and keeps cells functioning properly. A large portobello mushroom is said to have more potassium than a banana. Sodium and calcium are present in approximately equal concentrations in all the mushrooms except for Lentinus edodes in which calcium is present in excessively large amount. The copper is higher in all species of Pleurotus and varies from 12.2 to 21.9 ppm. $\mathrm{Cu}$ aids in helping the body to absorb the oxygen and create red blood cells. Calcium and lead contents vary from 0.3 to $0.5 \mathrm{ppm}$ and from 1.5 to 3.2 , respectively, in all species of Pleurotus. Of all the heavy metals, the zinc content is generally highest in all species of Pleurotus. Copper aids in helping the body to absorb oxygen and participate in formation of red blood cells. Selenium is an antioxidant 
TABLE 8: Levels of the trace metals ( $\mu \mathrm{g} / \mathrm{g}$, dry weight basis) in the analyzed mushroom samples.

\begin{tabular}{|c|c|c|c|c|c|c|c|c|c|c|c|}
\hline & $\mathrm{Mg}$ & $\mathrm{Cr}$ & $\mathrm{Mn}$ & $\mathrm{Fe}$ & Co & $\mathrm{Ni}$ & $\mathrm{Cu}$ & $\mathrm{Zn}$ & $\mathrm{Pb}$ & $\mathrm{Cd}$ & References \\
\hline $\begin{array}{l}\text { Cantharellus } \\
\text { cibarius }\end{array}$ & 866.3 & 1.57 & 22.09 & 118.2 & 0.05 & 1.07 & 32.49 & 54.29 & n.d. & 0.38 & [58] \\
\hline $\begin{array}{l}\text { Boletus } \\
\text { aureus }\end{array}$ & 755.1 & 0.86 & 18.3 & 112.8 & 0.18 & 1.61 & 41.4 & 89.4 & 0.09 & 0.23 & {$[58]$} \\
\hline $\begin{array}{l}\text { Lentinula } \\
\text { edodes }\end{array}$ & 40.7 & - & 1.00 & 14.8 & - & 0.15 & 1.48 & 9.44 & $\mathrm{BDL}$ & $\mathrm{BDL}$ & [59] \\
\hline $\begin{array}{l}\text { Lentinus } \\
\text { cladopus }\end{array}$ & 21.1 & - & 0.54 & 35.3 & - & 0.09 & 0.97 & 1.58 & $\mathrm{BDL}$ & $\mathrm{BDL}$ & [59] \\
\hline $\begin{array}{l}\text { Pleurotus } \\
\text { florida }\end{array}$ & 35.9 & - & 0.62 & 6.27 & - & 0.07 & 1.06 & 5.06 & 0.092 & $\mathrm{BDL}$ & [59] \\
\hline $\begin{array}{l}\text { Pleurotus } \\
\text { djamor }\end{array}$ & 31.6 & - & 1.12 & 14.8 & - & 0.15 & 1.45 & 9.21 & 0.12 & $\mathrm{BDL}$ & [59] \\
\hline $\begin{array}{l}\text { Pleurotus } \\
\text { ostreatus }\end{array}$ & 37.39 & - & 0.27 & 1.76 & - & - & 0.18 & 1.10 & - & - & {$[60]$} \\
\hline $\begin{array}{l}\text { Pleurotus } \\
\text { sajor-caju }\end{array}$ & 30.06 & - & 1.19 & 0.94 & - & - & 0.37 & 0.68 & - & - & {$[60]$} \\
\hline $\begin{array}{l}\text { Calocybe } \\
\text { indica }\end{array}$ & 51.21 & - & 0.53 & 1.81 & - & - & 0.91 & 0.78 & - & - & {$[60]$} \\
\hline
\end{tabular}

BDL: below detectable level.

that helps to neutralize free radicals, thus preventing cell damage and reducing the risk of cancer and other diseases. Mushrooms contain more selenium than any other form of produce. Potassium is an extremely important mineral that regulates blood pressure and keeps cells functioning properly. Other important minerals such as phosphorus, zinc, and magnesium are also found in mushrooms. Table 8 depicts levels of different metals in important edible mushrooms.

3.8. Nucleic Acids and Nucleotide Derivatives. Nucleotides are organic molecules that serve as the monomers, or subunits, of nucleic acids like DNA and RNA. Nucleotides serve to carry packets of energy within the cell (ATP). In the form of the nucleoside triphosphates (ATP, GTP, CTP, and UTP), nucleotides play central roles in metabolism. Nucleoside compounds produced by basidiomycetous fungi have also been investigated in detail and some of them have exhibited interesting bioactive potential. For example, shiitake mushrooms Lentinus edodes whose fruit bodies are cultivated on fallen logs in Japan for their value as edible delicacies are also a source of lentinacin, a nucleoside compound with hypoglycemic (cholesterol lessening) activity. Clitocybe inversa has been described as producing an insecticidal metabolite termed clitocine. Microorganisms are characterized by a high nucleic acid content. Viikari and Linko [62] have reported that the nucleic acid content of microorganisms is in the range of 8 to $25 \%$ (dry weight), while those of algae and fungi are known to be 3 to $8 \%$ and 3.2 to $4.7 \%$ (dry weight), respectively [61]. The nucleic acid content of mushrooms in comparison with other sources is given in Table 9. The practical safe limit of nucleic acid intake of most adult populations is a daily maximum of $4 \mathrm{~g}$ as suggested by the Protein Advisory Group of the United Nations System [91]. This is because man lacks the urate oxidase enzyme for the oxidation of uric acid, which is the sparingly soluble metabolic product of
TABLE 9: Nucleic acid content of some edible mushrooms and other food.

\begin{tabular}{lcc}
\hline Samples & Nucleic acid content & Source \\
\hline Yeast & $6.0-12.0 \%$ dry weight & {$[61]$} \\
Bacteria & $8.0-16.0 \%$ dry weight & {$[61]$} \\
Algae & $3.0-8.0 \%$ dry weight & {$[61]$} \\
Cereals & $1.1-4.0 \mathrm{~g} / 100$ g protein & {$[61]$} \\
Meat and fish & $2.2-5.7 \mathrm{~g} / 100$ g protein & {$[61]$} \\
Microorganisms & $8.0-25.0 \mathrm{~g} / 100$ g protein & {$[62]$} \\
Mushrooms & $2.7-4.1 \%$ dry weight & {$[63]$} \\
\hline
\end{tabular}

TABLE 10: Nucleic acid content of four edible mushrooms [63].

\begin{tabular}{lc}
\hline Mushrooms & $\begin{array}{c}\text { Percent nucleic acid content } \\
\text { (dry weight basis) }\end{array}$ \\
\hline Agaricus bisporus & 2.66 \\
Pleurotus cystidiosus & 2.93 \\
Pleurotus sajor-caju & 4.06 \\
Volvariella volvacea & 3.88 \\
\hline
\end{tabular}

purine bases guanine and adenine [92]. As given in Table 10, Pleurotus sajor-caju contains the highest amount of nucleic acids among the four edible mushrooms that were studied, $4.06 \%$ on a dry weight basis. Accordingly, it is safe to consume as much as $392.5 \mathrm{~g}$ of fresh $P$. sajor-caju daily. The limit could be higher for mushrooms with lower nucleic acid content.

\section{Therapeutic Metabolites of Mushrooms}

Fungi are nature's most accomplished chemists. The compounds they synthesize range from simple ubiquitous molecules such as gluconic and citric acid, often referred to 
as primary metabolites, to complex unusual molecules such as aflatoxin and ergot alkaloids, which are called secondary metabolites. Hundreds of medicinal mushrooms have been identified and their bioactive metabolites have been successfully used for the treatment of various diseases. These mushrooms are well known for their industrial and medicinal applications and a lot of work has been reported on these aspects by various workers. The climatic conditions prevailing in India have made it a natural habitat of large number of diverse mushroom florae and their metabolites. The use of mushrooms as medicine was mentioned by Berkeyley [35]. He also reported the use of Calvatia gigantea (giant puffball) and C. caelata in burnt cases due to their anaesthetic activity. They are also used to stop bleeding from wounds. Notable medicinal mushrooms with a well-documented history of use include Agaricus subrufescens, Ganoderma lucidum, and Ophiocordyceps sinensis. Research has identified compounds produced by these fungi have inhibitory biological effects against viruses and cancer cells. Specific metabolites, such as polysaccharide- $\mathrm{K}$, ergotamine, and $\beta$-lactam antibiotics, are routinely used in clinical medicine. The shiitake mushroom is a source of lentinan, a clinical drug approved for use in cancer treatments in several countries. In Europe and Japan, polysaccharide-K (brand name, Krestin), a chemical derived from Trametes versicolor, is an approved adjuvant for cancer therapy. The wood rotting fungus Ganoderma lucidum is an example that is cultivated today for its reputed medicinal benefits. Metabolites like nucleotides, nucleosides, proteins, amino acids, vitamins, polysaccharides, and triterpenoids have been reported to show activities like antitumor, antiallergic, antiviral, anti-inflammatory activities, antiageing effect, hepatoprotective effect, hypoglycemic activity, and cardiovascular effect. They are used for the treatment of chronic hepatitis. They are useful for enhancing vital energy, increasing thinking ability, and preventing forgetfulness. Extracts and powders derived from G. lucidum are being marketed in the form of capsules or sugar-coated tablets as a cure of many diseases. Polysaccharides, proteins, lipids, enzymes, vitamins, and minerals from Lentinus edodes are reported to treat dizziness and headache and used as a health tonic. Lentinan isolated from Lentinus edodes has antitumor activity. Active principles are said to be immune stimulating polysaccharides strengthening health and immunity [65]. Agaricus bisporus has been reported for its 2,2-diphenyl-1-picryl-hydrazylhydrate (DPPH) radical scavenging and total antioxidant capacity [93]. Pleurotus ostreatus has also been reported for its hypocholesterolemic, hypoglycemic, and hypolipidemic properties. Mushrooms have significant pharmacological effects or physiological properties, such as bioregulation (immunological enhancement), maintenance of homeostasis, regulation of biorhythm, cure of various diseases, prevention and improvement of life threatening diseases such as cancer, cerebral stroke, heart diseases, and immune deficiency diseases (including AIDS), or generation of immunosuppression during treatment [94]. A vast chemodiversity of the compounds has been reported in various mushrooms and important among them have been discussed below.
4.1. Polysaccharides. Polysaccharides are the best known metabolite present in mushrooms with antitumor and immunomodulating properties. $\beta$-D-glucans are a type of polysaccharide found in mushrooms that give them some medicinal properties. $\beta$-D-glucans bind to certain receptors on the surface of macrophages and other white blood cells. $\beta$-D-glucans have been shown to stimulate the production of some cytokines. They also help in prevention of asthma. Biologically active polysaccharides are widespread among higher basidiomycetous mushrooms, and most of them have unique structures in different species. These polysaccharides have different compositions, most belonging to the group of $\beta$-D-glucans; these have $\beta$-(1-3) linkages in the main chain of glucan and additional $\beta-(1-6)$ branch points. High molecular weight glucans appear to be more effective than those of low molecular weight. Moreover, different strains can produce polysaccharides with different properties. For example, the proteoglycan Krestin was developed in Japan from the strain Trametes (Coriolus) versicolor CM-101, whereas polysaccharide-peptide (PSP) in China was developed in submerged culture from the strain Cov-1 of the same species. Table 11 shows the bioactivity of polysaccharides of some important mushrooms.

4.2. Terpenoids. Terpenes are known as an important variety of naturally occurring bioactive metabolites produced by many higher fungi. Diterpenoids, triterpenoids, and sesquiterpenoid are the typical representatives of terpenes with interesting biological activities. Terpenoids are known to show anti-infectious and anti-inflammatory activities. Triterpenoids are mainly common among fungal metabolites. Terpenoid compounds, particularly sesquiterpenoids of unique structure, characterize many basidiomycetes and while they are not found in other microbes, some of them have homologies with plant terpenoid compounds. Triterpenoids isolated from Ganoderma lucidum are a class of naturally occurring compounds and structurally highly oxidized lanostanes. Accumulated data show that triterpenoids exhibit a broad spectrum of anticancer properties, including antiproliferative, antimetastatic, and antiangiogenic activities [95]. About 80 terpenoids including ganoderic acid derivatives have been isolated from the fruit bodies and the mycelia of G. lucidum [96-105]. Some of them have shown cytotoxicity against hepatoma cells in vitro (ganoderic acids $\mathrm{U}, \mathrm{V}, \mathrm{W}, \mathrm{X}$, and $\mathrm{Y}$ ), antihistamine releasing activity in rat mast cells (ganoderic acids $C$ and D), inhibitory activity against angiotensin converting enzyme (ganoderic acid F), hepatoprotective activity (ganoderic acid A), and an inhibitory effect on farnesyl protein transferase (ganoderic acid A and methyl ganoderate A) [105]. Merulius tremellosus produced a sesquiterpene dialdehyde named Merulidial 1 having high antifungal activity. Likewise, Marasmius alliaceus has been the source of unsaturated sesquiterpene showing high toxic properties and inhibiting nucleic acid synthesis in carcinoma cells. Lentinellic acid obtained from Lentinellus omphalodes exhibited strong antibacterial activity towards Gram positive as well as negative bacteria such as Bacillus subtilis and Aerobacter aerogenes and also inhibited to a significant extent DNA, RNA, and protein synthesis in Ehrlich 
TABLE 11: Source, type, and bioactivity of some mushroom polysaccharides.

\begin{tabular}{|c|c|c|c|c|}
\hline Mushroom name & Polysaccharide source & Type of polysaccharide & Bioactivity & References \\
\hline $\begin{array}{l}\text { Pleurotus } \\
\text { tuber-regium }\end{array}$ & Sclerotium, mycelium & $\beta$-D-glucan & Hepatoprotective, antibreast cancer & {$[64]$} \\
\hline Ganoderma lucidum & Fruiting body, culture broth & $\begin{array}{l}\text { Heteroglycan, } \\
\text { mannoglucan, glycopeptide }\end{array}$ & $\begin{array}{l}\text { Hyperglycemia, } \\
\text { immunomodulating, antitumor, } \\
\text { antioxidative, antidecrepitude }\end{array}$ & {$[64]$} \\
\hline Auricularia auricular & Fruiting body & Glucan & $\begin{array}{l}\text { Hyperglycemia, } \\
\text { immunomodulating, antitumor, } \\
\text { anti-inflammatory, antiradiative }\end{array}$ & {$[64]$} \\
\hline $\begin{array}{l}\text { Schizophyllum } \\
\text { commune }\end{array}$ & Mycelium & Glucan, schizophyllan & Antitumor & {$[64]$} \\
\hline Hericium erinaceus & Fruiting body, mycelium & $\begin{array}{l}\text { Heteroglycan, heteroglycan } \\
\text { peptide }\end{array}$ & $\begin{array}{l}\text { Hyperglycemia, } \\
\text { immunomodulating, antitumor }\end{array}$ & {$[64]$} \\
\hline Lentinus edodes & $\begin{array}{l}\text { Culture broth, fruiting } \\
\text { body }\end{array}$ & $\begin{array}{l}\text { Mannoglucan, } \\
\text { polysaccharide-protein } \\
\text { complex, glucan, lentinan }\end{array}$ & $\begin{array}{l}\text { Immunomodulating, antitumor, } \\
\text { antiviral }\end{array}$ & {$[64]$} \\
\hline $\begin{array}{l}\text { Sclerotinia } \\
\text { sclerotiorum }\end{array}$ & Sclerotium & Glucan, scleroglucan (SSG) & Antitumor & {$[64]$} \\
\hline Polystictus versicolor & $\begin{array}{l}\text { Fruiting body, culture } \\
\text { broth, mycelium }\end{array}$ & $\begin{array}{l}\text { Heteroglycan, glycopeptide, } \\
\text { Krestin (PSK) }\end{array}$ & $\begin{array}{l}\text { Immunomodulating, antitumor, } \\
\text { antiradiative, hyperglycemia, } \\
\text { anti-inflammatory }\end{array}$ & {$[64]$} \\
\hline Grifola frondosa & Fruiting body & $\begin{array}{l}\text { Proteoglycan, glucan, } \\
\text { galatomannan, } \\
\text { heteroglycan, and grifolan }\end{array}$ & $\begin{array}{l}\text { Immunomodulating, antitumor, } \\
\text { antiviral, hepatoprotective }\end{array}$ & {$[64]$} \\
\hline Inonotus obliquus & Fruiting body, mycelium & Glucan & Antitumor, immunomodulating & {$[64]$} \\
\hline Agaricus blazei & Fruiting body, mycelium & $\begin{array}{l}\text { Glucan, heteroglycan, } \\
\text { glucan protein, } \\
\text { Glucomannan-protein } \\
\text { complex }\end{array}$ & Antitumor & {$[64]$} \\
\hline Flammulina velutipes & Fruiting body, mycelium & $\begin{array}{l}\text { Glucan-protein complex, } \\
\text { glycoprotein }\end{array}$ & $\begin{array}{l}\text { Antitumor, anti-inflammatory, } \\
\text { antiviral, immunomodulating }\end{array}$ & {$[64]$} \\
\hline $\begin{array}{l}\text { Ganoderma } \\
\text { applanatum }\end{array}$ & Fruiting body & Glucan & Antitumor & {$[64]$} \\
\hline Polyporus umbellatus & Mycelium & Glucan & Antitumor, immunomodulating & {$[64]$} \\
\hline Clitopilus caespitosus & Fruiting body & Glucan & Antitumor & {$[64]$} \\
\hline $\begin{array}{l}\text { Pleurotus } \\
\text { citrinopileatus }\end{array}$ & Fruiting body & Galactomannan & Antitumor & {$[64]$} \\
\hline Trametes robiniophila & Mycelium & Proteoglycan & $\begin{array}{l}\text { Immunomodulating, } \\
\text { hepatoprotective, anticancer }\end{array}$ & {$[64]$} \\
\hline Tremella fuciformis & $\begin{array}{l}\text { Fruiting body, mycelium, } \\
\text { culture broth }\end{array}$ & Heteroglycan & $\begin{array}{l}\text { Hyperlipidemia, hyperglycemia, } \\
\text { immunomodulating, antitumor, } \\
\text { antidecrepitude, antithrombus }\end{array}$ & {$[64]$} \\
\hline Tremella aurantialba & Fruiting body, mycelium & Heteroglycan & $\begin{array}{l}\text { Immunomodulating, } \\
\text { hyperglycemia }\end{array}$ & {$[64]$} \\
\hline Pleurotus ostreatus & Fruiting body & Glycoprotein & $\begin{array}{l}\text { Antitumor, hyperglycemia, } \\
\text { antioxidant }\end{array}$ & {$[64]$} \\
\hline Morchella esculenta & Fruiting body & Heteroglycan & Hyperglycemia, antitumor & {$[64]$} \\
\hline Omphalia lapidescens & Fruiting body & Glucan & $\begin{array}{l}\text { Anti-inflammatory, } \\
\text { immunomodulating }\end{array}$ & {$[64]$} \\
\hline Phellinus linteus & Fruiting body & Glucan & Antitumor & {$[64]$} \\
\hline Armillariella tabescens & Mycelium & Heteroglycan & Antitumor & {$[64]$} \\
\hline Dictyophora indusiata & Fruiting body & $\begin{array}{l}\text { Heteroglycan, mannan, } \\
\text { glucan }\end{array}$ & Antitumor, hyperlipidemia & {$[64]$} \\
\hline $\begin{array}{l}\text { Tricholoma } \\
\text { mongolium }\end{array}$ & Fruiting body & Glucan & Antitumor & {$[64]$} \\
\hline
\end{tabular}


TABLE 11: Continued.

\begin{tabular}{|c|c|c|c|c|}
\hline Mushroom name & Polysaccharide source & Type of polysaccharide & Bioactivity & References \\
\hline Cordyceps sp. & $\begin{array}{l}\text { Fruiting body, mycelium, } \\
\text { culture broth }\end{array}$ & Glucan, heteroglycan & $\begin{array}{l}\text { Antitumor, immunomodulating, } \\
\text { antitumor, hyperglycemia }\end{array}$ & {$[64]$} \\
\hline Coriolus versicolor & Fruiting body, mycelium & $\begin{array}{l}\text { Polysaccharides PSK and } \\
\text { PSP }\end{array}$ & $\begin{array}{l}\text { Antiviral effect on HIV and } \\
\text { cytomegalovirus in vitro and } \\
\text { anticancer }\end{array}$ & {$[65]$} \\
\hline $\begin{array}{l}\text { Marasmius } \\
\text { androsaceus }\end{array}$ & Fruiting body, mycelium & Polysaccharide & Analgesic/sedative effect & {$[66]$} \\
\hline Volvariella sp. & Fruiting body, mycelium & Polysaccharide & Cardiac tonic & {$[66]$} \\
\hline $\begin{array}{l}\text { Coprinellus } \\
\text { disseminatus }\end{array}$ & Fruiting body, mycelium & Polysaccharide & Antitumor & {$[67]$} \\
\hline Trametes coriolus & Fruiting body, mycelium & $\begin{array}{l}\text { Polysaccharide } \\
\text { PSP-a glycopeptides }\end{array}$ & Antitumor and immunostimulant & {$[67]$} \\
\hline $\begin{array}{l}\text { Tricholomopsis } \\
\text { rutilans }\end{array}$ & Fruiting body, mycelium & $\begin{array}{l}\text { Polysaccharides } \\
\text { extract }\end{array}$ & $\begin{array}{l}\text { Anticarcinogenic activity } \\
\text { Antioxidative and } \\
\text { anti-inflammatory }\end{array}$ & {$[65]$} \\
\hline Tremella fuciformis & Fruiting body, mycelium & Polysaccharide & Hypocholesteric and hypolipidemic & [67] \\
\hline $\begin{array}{l}\text { Schizophyllum } \\
\text { commune }\end{array}$ & Fruiting body, mycelium & $\begin{array}{l}\text { Polysaccharide } \\
\text { schizophyllan }\end{array}$ & Antitumor effect & {$[67]$} \\
\hline
\end{tabular}

ascetic carcinoma cells. The terpenoids, namely, Illudin-M and Illudin-S, extracted from Clitocybe illudens are very effective against Plasmodium gallinaceum [106].

4.3. Steroids. Steroids are a type of organic compound that contains a characteristic arrangement of four cycloalkane rings that are joined to each other. Examples of steroids include the dietary fat cholesterol, the sex hormones estradiol and testosterone, and the anti-inflammatory drug dexamethasone. Recently, two known sterols with new cyclooxygenase (COX) inhibitory and antioxidant activities were isolated from the fruiting bodies of Agrocybe aegerita which is an edible mushroom [107]. Additionally, Wu et al. [108] reported that two novel secoergosterols, tylopiol A (106) and tylopiol B (107), were isolated from the fresh fruiting bodies of Tylopilus plumbeoviolaceus.

4.4. Glycoproteins. Glycoproteins are proteins that contain oligosaccharide chains (glycans) covalently attached to polypeptide side-chains by process known as glycosylation. Phallolysin is a glycoprotein obtained from Amanita phalloides which causes cytolysis of many mammalian cells [109]. Two distinct lectins, TML-1 and TML-2, with hemagglutinating and antiproliferative activity have been isolated from the cultured mycelium of the edible mushroom Tricholoma mongolicum [110].

4.5. Polyketides. Higher fungi have been recognized as profile producers of polyketides in the past as well as in the present. Polyketides are a class of secondary metabolites produced by almost all living organisms. These are structurally complex organic compounds that are often highly active biologically. Many pharmaceuticals are derived from or inspired by polyketides. Polyketides are structurally a very diverse family of natural products with diverse biological activities and pharmacological properties. Polyketides are the most abundant medicinal sources that have been shown to display a wide range of potentially useful therapeutic values like antibiotic, anticancer, antifungal, hypolipidemic, and immunosuppressive properties [111].

4.6. Others. Higher basidiomycetes especially mushrooms possess unlimited and useful therapeutic metabolites including alkaloids, flavonoids, saponins, tannins, anthraquinones, and steroids. Their presence makes these mushrooms popular to consume as good food sources and also valuable in drug development (Table 12).

Saponins are known to inhibit $\mathrm{Na}^{+}$efflux by blockage of the influx of concentration in the cells, activating $\mathrm{Na}^{+}-\mathrm{Ca}^{2+}$ antiporter in cardiac muscles. The increase in $\mathrm{Ca}^{2+}$ influx through this antiporter strengthens the contraction of heart muscles [112].

Alkaloids have been reported in curing many deadly human diseases like AIDS, cancer, and lung diseases [113]. Alkaloids regulate $\mathrm{Na}^{+}$ions and channels and microbial activity, have stimulating properties, and induce immunogenic cell death. Alkaloids are also known to have inhibitory effects on angiogenesis and therefore are useful in inhibiting the growth of cancerous cells [114].

High flavonoids level may help to provide protection against oxidative stress induced diseases by contributing along with other antioxidant vitamins and enzymes to the total antioxidative defense system of the human body. Many studies have attributed that antioxidant properties are due to the presence of flavonoids [115]. Hence, this may be a reason for the high lipid peroxidation inhibition found in certain species of the studied mushrooms.

Anthraquinone has been shown in certain studies to help in digestion as a laxative, to reduce inflammation in arthritis patients, and to inhibit the growth of cancer cells.

Triterpene glycoside affects the activity of the gastrointestinal tract; cyanogenic glycosides interfere with iodine 
TABLE 12: Miscellaneous therapeutic metabolites of mushrooms and their bioactivity.

\begin{tabular}{|c|c|c|c|}
\hline Mushroom name & Active principle & Activity & Reference \\
\hline $\begin{array}{l}\text { Ganoderma lucidum } \\
\text { Common name: Reishi }\end{array}$ & $\begin{array}{l}\text { Triterpenes, Ganoderiol F } \\
\text { Ganoderic acid B } \\
\text { Ganodermanontriol. } \\
\text { Ganodermadiol } \\
\text { Polysaccharide (ganopoly) } \\
\text { Triterpenes } \\
\text { Polysaccharides Ganoderon A, } \\
\text { Ganoderon B, Ganoderon C } \\
\beta \text {-D-glucan } \\
\text { Glycoprotein }\end{array}$ & $\begin{array}{l}\text { Active against HIV-1 } \\
\text { Cytotoxic to hepatoma cells } \\
\text { Active against herpes simplex virus-1 } \\
\text { Causing palliative effect on cancer related } \\
\text { symptoms and hepatitis B treatment } \\
\text { Protection against atherosclerosis } \\
\text { Hypoglycemic effect during treatment of type } 2 \\
\text { diabetics } \\
\text { Immunostimulative antitumor activity } \\
\text { Antitumor activity }\end{array}$ & {$[65,67]$} \\
\hline Ganoderma applanatum & $\begin{array}{l}\text { Steroids } \\
\text { Applanoxidic acid G } \\
\text { Applanoxidic acid G }\end{array}$ & $\begin{array}{l}\text { Antagonist to both Gram positive and Gram } \\
\text { negative bacteria } \\
\text { Active against influenza virus type A } \\
\text { Active against mouse skin tumor promoters } \\
\text { Useful in treatments of pain }\end{array}$ & {$[65]$} \\
\hline $\begin{array}{l}\text { Lentinula edodes } \\
\text { Common name: shiitake }\end{array}$ & $\begin{array}{l}\text { Oxalic acid present on caps } \\
\text { Polysaccharide lentinan } \\
\text { Emitanin } \\
\text { Soluble lignin } \\
\text { Eritadenine (a nucleotide derivative) }\end{array}$ & $\begin{array}{l}\text { Antibacterial activity } \\
\text { Inhibits Sarcoma } 180 \text { and HIV induced } \\
\text { cytopathic effect } \\
\text { Used in tumor/chemo/radiotherapy/surgery } \\
\text { Anti-HIV activities } \\
\text { Antilipidemic activity and reduces risk of } \\
\text { atherosclerosis }\end{array}$ & {$[65]$} \\
\hline Flammulina velutipes & $\begin{array}{l}\text { Sesquiterpenes, proteins, and } \\
\text { polysaccharides } \\
\text { Enokipodins } \\
\text { Velutin protein } \\
\text { Alcoholic and hot water extracts of its } \\
\text { sporophores }\end{array}$ & $\begin{array}{l}\text { Antitumor } \\
\text { Antifungal and antibacterial } \\
\text { Inactivating ribosome and inhibiting HIV-1 } \\
\text { reverse transcriptase } \\
\text { Cytostatic effects against tumor cells } \\
\text { Antiallergic and anticomplementary effects }\end{array}$ & {$[65]$} \\
\hline Auricularia- auricula judae & Acidic heteroglycans & Antitumor & {$[65]$} \\
\hline Auricularia polytricha & $\begin{array}{l}\text { Antiplatelet compound } \\
\text { Adenosine }\end{array}$ & Arhterosclerotic activity & {$[65]$} \\
\hline Pleurotus ostreatus & Lovastatin & Arhterosclerotic activity & {$[65]$} \\
\hline Grifola frondosa & $\begin{array}{l}\text { Polysaccharide } \beta \text {-D-glucan } \\
\text { Maitake D-fraction } \\
\text { Proteins with } \beta \text {-D-glucan } \\
\text { (Grifolan) } \\
\text { Xyloglucan, fucomannoglucan } \\
\text { Heteroglucans proteins } \\
\text { Mannogalactofucan } \\
\text { Heteroxylan } \\
\text { Galactomannoglycan }\end{array}$ & $\begin{array}{l}\text { Antiviral activity and immunostimulatory } \\
\text { effect } \\
\text { HIV-antitumor activity } \\
\text { Antitumor activity }\end{array}$ & {$[67]$} \\
\hline Laetiporus sulphureus & Dehydrotrametenolicacid & $\begin{array}{l}\text { Hypoglycemic activity } \\
\text { Insulin sensitizer and reducing hyperglycemia }\end{array}$ & {$[67]$} \\
\hline Lenzites betulina & Betulinam A & Radical scavenger & [67] \\
\hline Cordyceps militaris & $\begin{array}{l}\text { Polysaccharides (Cordycepic acid and } \\
\beta \text {-D-glucans) } \\
\text { Triterpenoids } \\
\text { Nucleosides (cordycepin, } \\
\text { 3-deoxyadenosine) } \\
\text { Proteins, amino acids } \\
\text { Vitamins (B-complex and ascorbic acid) } \\
\text { Minerals (trace elements) }\end{array}$ & $\begin{array}{l}\text { Cancer } \\
\text { Fatigue } \\
\text { Respiratory and pulmonary diseases } \\
\text { Liver and renal disorders } \\
\text { Male and female sexual dysfunctions } \\
\text { Cardiovascular diseases }\end{array}$ & {$[65]$} \\
\hline Cordyceps sinensis & Adenosine, cordycepin, and ergosterol & Antioxidative property & {$[68]$} \\
\hline
\end{tabular}


TABLE 12: Continued.

\begin{tabular}{lll}
\hline Mushroom name & Active principle & Activity \\
\hline $\begin{array}{l}\text { Morchella esculenta } \\
\text { enzymes, vitamins, } \\
\text { minerals, and amino acids } \\
\text { No cholesterol }\end{array}$ & $\begin{array}{l}\text { Cures pneumonia, fever, cough, cold, and } \\
\text { stomachache } \\
\text { Cures diseases for pregnant and lactating } \\
\text { minerals } \\
\text { For respiratory ailments }\end{array}$ \\
\hline Pleurotus sajor-caju & $\begin{array}{l}\text { Proteins having polysaccharide } \\
\text { xyloglucan, xyloproteins }\end{array}$ & Antitumor \\
\hline Agaricus campestris & Glycoproteins & Antitumor \\
\hline Boletus edulis & [65] & Antitumor \\
\hline Calvatia gigantea & Calvacin & Antitumor \\
\hline Cyathus stercoreus & $\begin{array}{l}\text { Polyketide } \\
\text { Cyathusals A, B, and C } \\
\text { Pulvinatal antioxidant effect }\end{array}$ & Antitumor \\
\hline Tricholomopsis rutilans & $\begin{array}{l}\text { Polysaccharides } \\
\text { Phenol fosmicin B }\end{array}$ & [67] \\
\hline Oudemansiella radicata & E-b methoxy acrylate & $\begin{array}{l}\text { Antitumor, anti-inflammatory, and } \\
\text { antioxidant }\end{array}$ \\
\hline Collybia velutipes & Eritadenine & Antibiotic effect \\
\hline [67]
\end{tabular}

organification and thus can cause or promote goiter and hypothyroidism. An array of glycosidic compounds is currently used in medicine. It involves glycosides of vitamins, polyphenolic glycosides (flavonoids), alkaloid glycosides, glycosides in the group of antibiotics, glycopeptides, cardiac glycosides, steroid and terpenoid glycosides, and so forth.

Many tannin molecules have also been shown to reduce the mutagenic activity of a number of mutagens. Many carcinogens and/or mutagens produce oxygen-free radicals for interaction with cellular macromolecules. The anticarcinogenic and antimutagenic potentials of tannins may be related to their antioxidative property, which is important in protecting cellular oxidative damage, including lipid peroxidation [116].

\section{Conclusion}

The need to maintain or rebuild a healthy defense mechanism has led researchers in search of natural health supporting properties from fungi including mushrooms. Human beings have constantly searched for new substances that can steadily and efficiently improve biological functions. Nutraceuticals are destined to play important role in future therapeutic developments. There are evidences that beneficial treatment of some diseases can also be obtained by consumption of functional foods or through the use of extracted biologically active compounds in the form of nutraceuticals/dietary supplements. The mushroom family in particular shows promise for its ability to enhance immune function. Mushrooms grow wild in many parts of the world and are also commercially cultivated. Nutritionally, mushrooms are a valuable health food and have been used medicinally for centuries in various parts of the world. Although the nutritional facts and culinary uses of mushrooms are well adapted, the fungi's medicinal qualities have yet to make the mainstream.

\section{Conflict of Interests}

The authors declare that there is no conflict of interests regarding the publication of this paper.

\section{References}

[1] D. K. Rahi, R. C. Rajak, K. K. Shukla, and A. K. Pandey, "Diversity and nutraceutical potential of wild edible mushrooms of Central India," in Microbial Diversity: Current Perspectives and Potential Applications, pp. 967-980, 2005.

[2] Z. Bano, "The nutritive value of mushrooms," in Proceeding of First Symposium on Survey and Cultivation of Edible Mushroom of India, vol. 2, pp. 148-160, Regional Research Laboratory, Srinagar, India, 1976.

[3] S. T. Chang and P. G. Miles, "Introduction to mushroom science," in The Tropical Mushroom-Biological Nature and Cultivation Methods, S. T. Chang and T. H. Quimio, Eds., The Chinese University Press, Hong Kong, 1982.

[4] V. P. Gupta, "Mushroom yield- a rich food-a profitable commercial crop," Kisan World, vol. 37, 1989.

[5] H. S. Sohi, "Mushroom culture in India, recent research findings," Indian Phytopathology, vol. 41, pp. 313-326, 1988.

[6] D. K. Rahi, K. K. Shukla, R. C. Rajak, and A. K. Pandey, "Agaricales of Central India II: a new species of Cantharellus," Indian Journal of Mushrooms, In press.

[7] C. Lull, H. J. Wichers, and H. F. J. Savelkoul, "Anti-inflammatory and immunomodulating properties of fungal metabolites," Mediators of Inflammation, vol. 2005, no. 2, pp. 63-80, 2005.

[8] P. Roberts and S. Evans, The Book of Fungi, Ivy Press, Lewes, UK, 2013.

[9] C. J. Alexopolous, C. W. Mims, and M. Blackwell, Introductory Mycology, 4th edition, 2002.

[10] S. T. Chang, "Mushroom and mushroom biology," in Genetics and Breeding of Edible Mushrooms, S. T. Chang, J. A. Bushwell, and P. G. Miles, Eds., pp. 1-3, CRC Press, 1993. 
[11] R. Singer, The Agaricales in Modern Taxonomy, Koeltz Scientific Books, Königstein, Germany, 1986.

[12] R. Watling, "Development characters of agarics," in Developmental Biology of Higher Fungi, D. Moore, L. A. Casselton, D. A. Wood, and J. C. Frankland, Eds., Cambridge University Press, Cambridge, UK, 1985.

[13] D. K. Rahi, K. K. Shukla, R. C. Rajak, and A. K. Pandey, "Agaricales of Central India I: two new species," Indian Journal of Mushrooms, vol. 21, no. 1-2, pp. 29-31, 2003.

[14] Y. Qu, H. B. Zhang, and J. K. Liu, "Isolation and structure of a new ceramide from the Basidiomycete Hygrophorus eburneus," Verlag der Zeitschrift für Naturforschung Section B, vol. 59, pp. 241-244, 2004.

[15] I. Riede, "Tumor therapy with Amanita phalloides (death cap): stabilization of B-cell chronic lymphatic leukemia," Journal of Alternative and Complementary Medicine, vol. 16, no. 10, pp. 1129-1132, 2010.

[16] J. Leichter and R. J. Bandoni, "Nutrient content of mushrooms grown in British Columbia," Canadian Institute of Food Science and Technology Journal, vol. 13, no. 3, pp. 122-124, 1980.

[17] S. M. Ayodele and J. A. Okhuoya, "Nutritional and phytochemical evaluation of cultivated Psathyrella atroumbonata Pegler, a Nigerian edible mushroom," South African Journal of Science, vol. 105, no. 3-4, pp. 158-160, 2009.

[18] H. Li, M. Zhang, and G. Ma, "Hypolipidemic effect of the polysaccharide from Pholiota nameko," Nutrition, vol. 26, no. 5, pp. 556-562, 2010.

[19] G. Q. Zhang, J. Sun, H. X. Wang, and T. B. Ng, "A novel lectin with antiproliferative activity from the medicinal mushroom Pholiota adiposa," Acta Biochimica Polonica, vol. 56, no. 3, pp. 415-421, 2009.

[20] J.-L. Mau, C.-N. Chang, S.-J. Huang, and C.-C. Chen, "Antioxidant properties of methanolic extracts from Grifola frondosa, Morchella esculenta and Termitomyces albuminosus mycelia," Food Chemistry, vol. 87, no. 1, pp. 111-118, 2004.

[21] A. Chatterjee, S. Khatua, S. Chatterjee et al., "Polysacchariderich fraction of Termitomyces eurhizus accelerate healing of indomethacin induced gastric ulcer in mice," Glycoconjugate Journal, vol. 30, no. 8, pp. 759-768, 2013.

[22] Y.-Y. Lu, Z.-H. Ao, Z.-M. Lu et al., "Analgesic and antiinflammatory effects of the dry matter of culture broth of Termitomyces albuminosus and its extracts," Journal of Ethnopharmacology, vol. 120, no. 3, pp. 432-436, 2008.

[23] H. Nomura, N. Inokuchi, H. Kobayashi et al., "Purification and primary structure of a new guanylic acid specific ribonuclease from Pleurotus ostreatus," The Journal of Biochemistry, vol. 116, no. 1, pp. 26-33, 1994.

[24] E. Boa, Wild Edible Fungi: A Global Overview of Their Use and Importance to People, FAO, 2007.

[25] V. P. Sharma, S. Kumar, and R. P. Tiwari, Flammulina velutipes, The Culinary Medicinal Winter Mushroom, vol. 6 of Medicinal Attributes and Their Properties, 2009.

[26] G.-Q. Liu and K.-C. Zhang, "Mechanisms of the anticancer action of Ganoderma lucidum (Leyss. ex Fr.) karst.: a new understanding," Journal of Integrative Plant Biology, vol. 47, no. 2, pp. 129-135, 2005.

[27] D. A. Aina, S. G. Jonathan, O. J. Olawuyi, D. O. Ojelabi, and B. M. Durowoju, "Antioxidant, antimicrobial and phytochemical properties of alcoholic extracts of Cantharellus cibarius-a Nigerian mushroom," New York Science Journal, vol. 5, no. 10, pp. 114-120, 2012.
[28] C. Méndez-Espinoza, E. García-Nieto, A. Montoya Esquivel et al., "Antigenotoxic potential of aqueous extracts from the chanterelle mushroom, Cantharellus cibarius (higher Basidiomycetes), on human mononuclear cell cultures," International Journal of Medicinal Mushrooms, vol. 15, no. 3, pp. 325-332, 2013.

[29] V. E. C. Ooi and F. Liu, "Immunomodulation and anti-cancer activity of polysaccharide-protein complexes," Current Medicinal Chemistry, vol. 7, no. 7, pp. 715-729, 2000.

[30] M.-Y. Jiang, L. Zhang, Z.-J. Dong, and J.-K. Liu, “Two new metabolites from basidiomycete Sparassis crispa," Zeitschrift für Naturforschung B, vol. 64, no. 9, pp. 1087-1089, 2009.

[31] T. Kimura, "Natural products and biological activity of the pharmacologically active cauliflower mushroom Sparassis crispa," BioMed Research International, vol. 2013, Article ID 982317, 9 pages, 2013.

[32] H. X. Wang, T. B. Ng, and Q. H. Liu, "Alveolarin, a novel antifungal polypeptide from the wild mushroom Polyporus alveolaris," Peptides, vol. 25, no. 4, pp. 693-696, 2004.

[33] S. Ukai, T. Kiho, C. Hara et al., "Polysaccharides in fungi: XIII. Antitumor activity of various polysaccharides isolated from Dictyophora indusiata, Ganoderma japonicum, Cordyceps cicadae, Auricularia auricula-judae and Auricularia sp," Chemical and Pharmaceutical Bulletin, vol. 31, no. 2, pp. 741-744, 1983.

[34] A. Misaki, M. Kakuta, T. Sasaki, M. Tanaka, and H. Miyaji, "Studies on interrelation of structure and antitumor effects of polysaccharides: antitumor action of periodate-modified, branched $(1 \rightarrow 3)$ - $\beta$-D-glucan of Auricularia auricula-judae, and other polysaccharides containing $(1 \rightarrow 3)$-glycosidic linkages," Carbohydrate Research, vol. 92, no. 1, pp. 115-129, 1981.

[35] J. M. Berkeyley, "Introduction to cryptogamic botany, London. H. Bailliere," Foods and Food Ingredients Journal of Japan, vol. 167, pp. 69-85, 1857.

[36] J. A. Buswell and S. T. Chang, "Edible mushrooms. Attributes and applications," in Genetics and Breeding of Edible Mushrooms, S. T. Chang, J. A. Buswell, and P. G. Miles, Eds., pp. 297394, Gordon and Breach, Philadelphia, Pa, USA, 1993.

[37] B. A. Oso, "Mushrooms in yoruba mythology and medicinal practices," Economic Botany, vol. 31, no. 3, pp. 367-371, 1977.

[38] E. Bautista-Nava and Á. Moreno-Fuentes, "First record of the edibility of Calostoma cinnabarina Desv. (Sclerodermatales)," Revista Mexicana de Biodiversidad, vol. 80, no. 2, pp. 561-564, 2009.

[39] M. Al-Fatimi, M. Wurster, H. Kreisel, and U. Lindequist, "Antimicrobial, cytotoxic and antioxidant activity of selected basidiomycetes from Yemen," Pharmazie, vol. 60, no. 10, pp. 776-780, 2005.

[40] S. K. Mallick, S. K. Bhutia, and T. K. Maiti, "Macrophage stimulation by polysaccharides isolated from barometer earthstar mushroom, Astraeus hygrometricus (Pers.) Morgan (Gasteromycetideae)," International Journal of Medicinal Mushrooms, vol. 11, no. 3, pp. 237-248, 2009.

[41] E. V. Crisan and A. Sands, "Nutritional value," in The Biology and Cultivation of Edible Mushrooms, S. T. Chang and W. A. Hayes, Eds., p. 137, Academic Press, New York, NY, USA, 1978.

[42] S. T. Chang, O. W. Lau, and K. Y. Cho, "The cultivation and nutritional value of Pleurotus sajor-caju," European Journal of Applied Microbiology and Biotechnology, vol. 12, no. 1, pp. 5862, 1981.

[43] G. S. F. Li and S. T. Chang, "Nutrititive value of Volvariella volvaceae in tropical mushrooms," in Biological Nature and Cultivation Methods, S. T. Chang and T. H. Quimio, Eds., p. 199, The Chinese University Press, Hong Kong, 1982. 
[44] T. O. Adejumo and O. B. Awosanya, "Proximate and mineral composition of four edible mushroom species from South Western Nigeria," African Journal of Biotechnology, vol. 4, no. 10, pp. 1084-1088, 2005.

[45] L. Barros, P. Baptista, D. M. Correia, S. Casal, B. Oliveira, and I. C. F. R. Ferreira, "Fatty acid and sugar compositions, and nutritional value of five wild edible mushrooms from Northeast Portugal," Food Chemistry, vol. 105, no. 1, pp. 140-145, 2007.

[46] E. C. Egwim and R. C. Elem, "Proximate composition, phytochemical screening and antioxidant activity of ten selected wild edible Nigerian mushrooms," American Journal of Food and Nutrition, vol. 1, no. 2, pp. 89-94, 2011.

[47] J. Gbolagade, A. Ajayi, I. Oku, and D. Wankasi, "Nutritive value of common wild edible mushrooms from Southern Nigeria," Global Journal of Biotechnology, vol. 1, no. 1, pp. 16-21, 2006.

[48] Z. Bano and S. Rajarathnam, "Pleurotus mushroom as a nutritious food," in Tropical Mushrooms-Biological Nature and Cultivation Methods, S. T. Chang and T. H. Quimio, Eds., p. 363, The Chinese University Press, Hong Kong, 1982.

[49] P. Surinrut, K. Julshamn, and L. R. Njaa, "Protein, amino acids and some major and trace elements in Thai and Norwegian mushrooms," Plant Foods for Human Nutrition, vol. 37, no. 2, pp. 117-125, 1987.

[50] V. A. Díez and A. Alvarez, "Compositional and nutritional studies on two wild edible mushrooms from northwest Spain," Food Chemistry, vol. 75, no. 4, pp. 417-422, 2001.

[51] P. Chirinang and K.-O. Intarapichet, "Amino acids and antioxidant properties of the oyster mushrooms, Pleurotus ostreatus and Pleurotus sajor-caju," ScienceAsia, vol. 35, no. 4, pp. 326-331, 2009.

[52] D. Agrahar-Murugkar and G. Subbulakshmi, "Nutritional value of edible wild mushrooms collected from the Khasi hills of Meghalaya," Food Chemistry, vol. 89, no. 4, pp. 599-603, 2005.

[53] P. Stamets, Growing Gourmet and Medicinal Mushrooms, Ten Speed Press, Berkeley, Calif, USA, 1993.

[54] J. G. Vaidya and A. S. Rabba, "Fungi in folk medicine," Mycologist, vol. 7, no. 3, pp. 131-133, 1993.

[55] W. Quack, T. Anke, F. Oberwinkler, B. M. Giannetti, and W. Steglich, "Antibiotics from Basidiomycetes V. Merulidial, a new nntibiotic from the basidiomycete, Merulius tremellosus," The Journal of Antibiotics, vol. 31, no. 8, pp. 737-741, 1978.

[56] T. C. Vanterpool and R. Marcae, "Notes on the Canadian Tuckahoe, its occurrence, in Canada and the infertility of its perfect stage, Polyporus tuberaster Jacq. Ex. Fries," Canadian Journal of Botany, vol. 29, no. 2, pp. 147-157, 1951.

[57] B. H. Huang, K. H. Yung, and S. T. Chang, "Fatty acid composition of Volvariella volvaceae and other edible mushrooms," Mushroom Science, vol. 12, 1989.

[58] P. K. Ouzouni, D. Petridis, W.-D. Koller, and K. A. Riganakos, "Nutritional value and metal content of wild edible mushrooms collected from West Macedonia and Epirus, Greece," Food Chemistry, vol. 115, no. 4, pp. 1575-1580, 2009.

[59] S. E. Mallikarjuna, A. Ranjini, D. J. Haware, M. R. Vijayalakshmi, M. N. Shashirekha, and S. Rajarathnam, "Mineral composition of four edible mushrooms," Journal of Chemistry, vol. 2013, Article ID 805284, 5 pages, 2013.

[60] M. K. Zahid, S. Barua, and S. M. I. Haque, "Proximate composition and mineral content of selected edible mushroom varieties of bangladesh," Bangladesh Journal of Nutrition, vol. 22-23, 2012.

[61] R. Kihlberg, "The microbe as a source of food," in Annual Review of Microbiology, L. E. Clifton, S. Raffel, and M. P. Starr, Eds., vol. 26, pp. 427-466, 1972.
[62] L. Viikari and M. Linko, "Reduction of nucleic acid content of SCP," Process Biochemistry, vol. 12, pp. 17-19, 1977.

[63] G. S. F. Li and S. T. Chang, "The nucleic acid content of some edible mushrooms," European Journal of Applied Microbiology and Biotechnology, vol. 15, no. 4, pp. 237-240, 1982.

[64] M. Zhang, S. W. Cui, P. C. K. Cheung, and Q. Wang, "Antitumor polysaccharides from mushrooms: a review on their isolation process, structural characteristics and antitumor activity," Trends in Food Science and Technology, vol. 18, no. 1, pp. 4-19, 2007.

[65] A. Sagar, C. Gautam, and A. K. Sehgal, "Studies on some medicinal mushrooms of Himachal Pradesh," Indian Journal of Mushrooms, vol. 25, pp. 8-14, 2007.

[66] S. H. Pai, S. C. Jong, and W. Low, "Usage of mushrooms," Bioindustry, vol. 1, pp. 126-131, 1990.

[67] S. T. Chang, J. A. Buswell, and S. W. Chiu, Mushroom Biology and Mushroom Products, The Chinese University of Hong Kong, 1993.

[68] R. K. Arora, R. P. Singh, and S. K. Guru, "Determination of bioactive compounds in medicinal mushroom, Cordyceps sinensis," Mushroom Research, vol. 17, no. 2, pp. 61-66, 2008.

[69] A. M. Jones and E. B. G. Jones, "Observations on the marine gasteromycete Nia vibrissa," Mycological Research, vol. 97, no. 1, pp. 1-6, 1993.

[70] V. Brower, "Nutraceuticals: poised for a healthy slice of healthcare market," Nature Biotechnology, vol. 16, no. 8, pp. 728-730, 1998.

[71] S. H. Zeisel, "Regulation of 'nutraceuticals"' Science, vol. 285, no. 5435, pp. 1853-1855, 1999.

[72] A. W. Chen and P. G. Miles, "Biomedical research and the application of mushroom nutraceuticals from Ganoderma lucidum," in Mushroom Biology and Mushroom Products, D. J. Royse, Ed., pp. 153-159, 1996.

[73] H. K. Biesalski, "Nutraceuticals: link between nutrition and medicine," in Nutraceuticals in Health and Disease Prevention, K. Kramer, P. P. Hoppe, and L. Packer, Eds., pp. 1-26, Marcel Dekker, New York, NY, USA, 2001.

[74] W. Andlauer and P. Fürst, "Nutraceuticals: a piece of history, present status and outlook," Food Research International, vol. 35, no. 2-3, pp. 171-176, 2002.

[75] J. E. Stauffer, "Nutraceuticals," Cereal Foods World, vol. 44, pp. 115-117, 1999.

[76] M. Whitman, "Understanding the perceived need for complementary and alternative nutraceuticals: lifestyle issues," Clinical Journal of Oncology Nursing, vol. 5, no. 5, pp. 190-194, 2001.

[77] S. T. Chang and J. A. Buswell, "Mushroom nutriceuticals," World Journal of Microbiology and Biotechnology, vol. 12, no. 5, pp. 473476, 1996.

[78] D. K. Rahi, K. K. Shukla, R. C. Rajak, and A. K. Pandey, "Nutritional potential of Termitomyces heimii: an important wild edible tribal mushroom species of M.P.", Journal of Basic and Applied Mycology, vol. 1, no. 1, pp. 36-38, 2002.

[79] S. Rajarathnam and Z. Bano, "Hand book of applied mycology," in Foods and Feeds, D. K. Arora, K. G. Mukherji, and E. H. Marth, Eds., pp. 241-292, Marcel Dekker, New York, NY, USA, 1993.

[80] S. T. Chang, "Mushrooms as human food," BioScience, vol. 30, no. 6, pp. 399-401, 1980.

[81] S. T. Chang and P. G. Miles, "The nutritional attributes and medicinal value of edible mushrooms," in Edible Mushrooms and Their Cultivation, pp. 27-39, CRC Press, 1993. 
[82] R. H. Boda, A. H. Wani, M. A. Zargar, B. A. Ganie, B. A. Wani, and S. A. Ganie, "Nutritional values and antioxidant potential of some edible mushrooms of Kashmir valley," Pakistan Journal of Pharmaceutical Sciences, vol. 25, no. 3, pp. 623-627, 2012.

[83] P. Mattila, A.-M. Lampi, R. Ronkainen, J. Toivo, and V. Piironen, "Sterol and vitamin D2 contents in some wild and cultivated mushrooms," Food Chemistry, vol. 76, no. 3, pp. 293-298, 2002.

[84] W. Breene, "Nutritional and medicinal value of speciality mushrooms," Journal of Food Protection, vol. 53, pp. 883-894, 1990.

[85] P. H. Mattila, V. I. Piironen, E. J. Uusi-Rauva, and P. E. Koivistoinen, "Vitamin D contents in edible mushrooms," Journal of Agricultural and Food Chemistry, vol. 42, no. 11, pp. 2449-2453, 1994.

[86] Z. Zrodlowski, "The influence of washing and peeling of mushrooms Agaricusbisporus on the level of heavy metal contaminations," Polish Journal of Food and Nutrition Sciences, vol. 4, pp. 23-33, 1995.

[87] P. Mattila, K. Suonpää, and V. Piironen, "Functional properties of edible mushrooms," Nutrition, vol. 16, no. 7-8, pp. 694-696, 2000.

[88] P. Mattila, K. Könkö, M. Eurola et al., "Contents of vitamins, mineral elements, and some phenolic compounds in cultivated mushrooms," Journal of Agricultural and Food Chemistry, vol. 49, no. 5, pp. 2343-2348, 2001.

[89] J. W. Anderson and K. Ward, "High-carbohydrate, high-fiber diets for insulin-treated men with diabetes mellitus," The American Journal of Clinical Nutrition, vol. 32, no. 11, pp. 2312-2321, 1979.

[90] G. V. Vahouny and D. Kritchevsky, Dietary Fiber-Basic and Clinical Aspects, Plenum Press, New York, NY, USA, 1986.

[91] Protein Advisory Group, Single-Cell Protein Guideline No. 4, FAO/WHO/UNICEF Protein Advisory Group, United Nations, New York, NY, USA, 1970.

[92] N. S. Scrimshaw, "Single cell protein for human consumption: an overview," in Single Cell Protein, S. R. Tannenbaum and D. I. V. Wang, Eds., vol. 2, pp. 1-4, MIT Press, Cambridge, Mass, USA, 1975.

[93] R. Singla, A. Ganguli, and M. Ghosh, "Antioxidant activities and polyphenolic properties of raw and osmotically dehydrated dried mushroom (Agaricus bisporous) snack food," International Journal of Food Properties, vol. 13, no. 6, pp. 1290-1299, 2010.

[94] S. P. Wasser and A. L. Weis, "Medicinal properties of substances occurring in higher Basidiomycetes mushrooms: current perspectives," International Journal of Medicinal Mushrooms, vol. 1, no. 1, pp. 31-62, 1999.

[95] G.-S. Wu, J.-J. Guo, J.-L. Bao et al., "Anti-cancer properties of triterpenoids isolated from Ganoderma lucidum-a review," Expert Opinion on Investigational Drugs, vol. 22, no. 8, pp. 981992, 2013.

[96] M. Hirotani, T. Furuya, and M. Shiro, "A ganoderic acid derivative, a highly oxygenated lanostane-type triterpenoid from Ganoderma lucidum," Phytochemistry, vol. 24, no. 9, pp. 2055-2061, 1985.

[97] H. Sato, T. Nishitoba, and S. Shirasu, "Ganoderiol A and B, new triterpenoids from the fungus Ganoderma lucidum (Reishi)," Agricultural and Biological Chemistry, vol. 50, no. 11, pp. 28872890, 1986.

[98] T. Nishitoba, S. Goto, H. Sato, and S. Sakamura, "Bitter triterpenoids from the fungus Ganoderma applanatum," Phytochemistry, vol. 28, no. 1, pp. 193-197, 1989.
[99] M. Hirotani, I. Asaka, C. Ino, T. Furuya, and M. Shiro, "Ganoderic acid derivatives and ergosta-4,7,22-triene-3,6-dione from Ganoderma lucidum," Phytochemistry, vol. 26, no. 10, pp. 2797-2803, 1987.

[100] L.-J. Lin, M.-S. Shiao, and S.-F. Yeh, "Triterpenes from Ganoderma lucidum," Phytochemistry, vol. 27, no. 7, pp. 2269-2271, 1988.

[101] M.-S. Shiao, L.-J. Lin, and S.-F. Yeh, “Triterpenes from Ganoderma lucidum," Phytochemistry, vol. 27, no. 9, pp. 2911-2914, 1988.

[102] T. Nishitoba, H. Sato, and S. Sakamura, "Triterpenoids from the fungus Ganoderma lucidum," Phytochemistry, vol. 26, no. 6, pp. 1777-1784, 1987.

[103] Chairul, T. Tokuyama, M. Nishizawa, M. Shiro, H. Tokuda, and Y. Hayashiji, "Malonate half-esters of homolanostanoid from an Asian Ganoderma fungus," Phytochemistry, vol. 29, no. 3, pp. 923-928, 1990.

[104] M. Hirotani and T. Furuya, "Changes of the triterpenoid patterns during formation of the fruit body in Ganoderma lucidum," Phytochemistry, vol. 29, no. 12, pp. 3767-3771, 1990.

[105] B.-S. Min, J.-J. Gao, N. Nakamura, and M. Hattori, “Triterpenes from the spores of Ganoderma lucidum and their cytotoxicity against Meth-A and LLC tumor cells," Chemical \& Pharmaceutical Bulletin, vol. 48, no. 7, pp. 1026-1033, 2000.

[106] T. C. McMorris and M. Anchel, "Fungal metabolites. The structures of the novel sesquiterpenoids illudin-S and -M," Journal of the American Chemical Society, vol. 87, no. 7, pp. 15941600, 1965.

[107] Y. Zhang, G. L. Mills, and M. G. Nair, "Cyclooxygenase inhibitory and antioxidant compounds from the fruiting body of an edible mushroom, Agrocybe aegerita," Phytomedicine, vol. 10, no. 5, pp. 386-390, 2003.

[108] S. H. Wu, X. D. Luo, Y. B. Ma et al., "Two novel secoergosterols from the fungus Tylopilusplum beoviolaceus," Journal of Natural Products, vol. 63, pp. 534-536, 2000.

[109] K. P. Odenthal, R. Seeger, and G. Vogel, "Toxic effects of phallolysin from amanita phalloides," Naunyn-Schmiedeberg's Archives of Pharmacology, vol. 290, no. 2-3, pp. 133-143, 1975.

[110] H. X. Wang, T. B. Ng, W. K. Liu, V. E. C. Ooi, and S. T. Chang, "Isolation and characterization of two distinct lectins with antiproliferative activity from the cultured mycelium of the edible mushroom Tricholoma mongolicum," International Journal of Peptide and Protein Research, vol. 46, no. 6, pp. 508513, 1995.

[111] J. Staunton and K. J. Weissman, "Polyketide biosynthesis: a millennium review," Natural Product Reports, vol. 18, no. 4, pp. 380-416, 2001.

[112] G. Schneider and J. Wölfling, "Synthetic cardenolides and related compounds," Current Organic Chemistry, vol. 8, no. 14, pp. 1381-1403, 2004.

[113] S. Mandal, A. Nayak, S. K. Banerjee, J. Banerji, and A. Banerji, "A new carbazole alkaloid from Murraya koenigii Spreng (Rutaceae)," Natural Product Communications, vol. 3, no. 10, pp. 1679-1682, 2008.

[114] T. Aniszewski, Alkaloids: Chemistry, Biology, Ecology and Applications, Elsevier, 2nd edition, 2015.

[115] J. B. Harborne and C. A. Williams, "Advances in flavonoid research since 1992," Phytochemistry, vol. 55, no. 6, pp. 481-504, 2000.

[116] K.-T. Chung, T. Y. Wong, C.-I. Wei, Y.-W. Huang, and Y. Lin, "Tannins and human health: a review," Critical Reviews in Food Science and Nutrition, vol. 38, no. 6, pp. 421-464, 1998. 

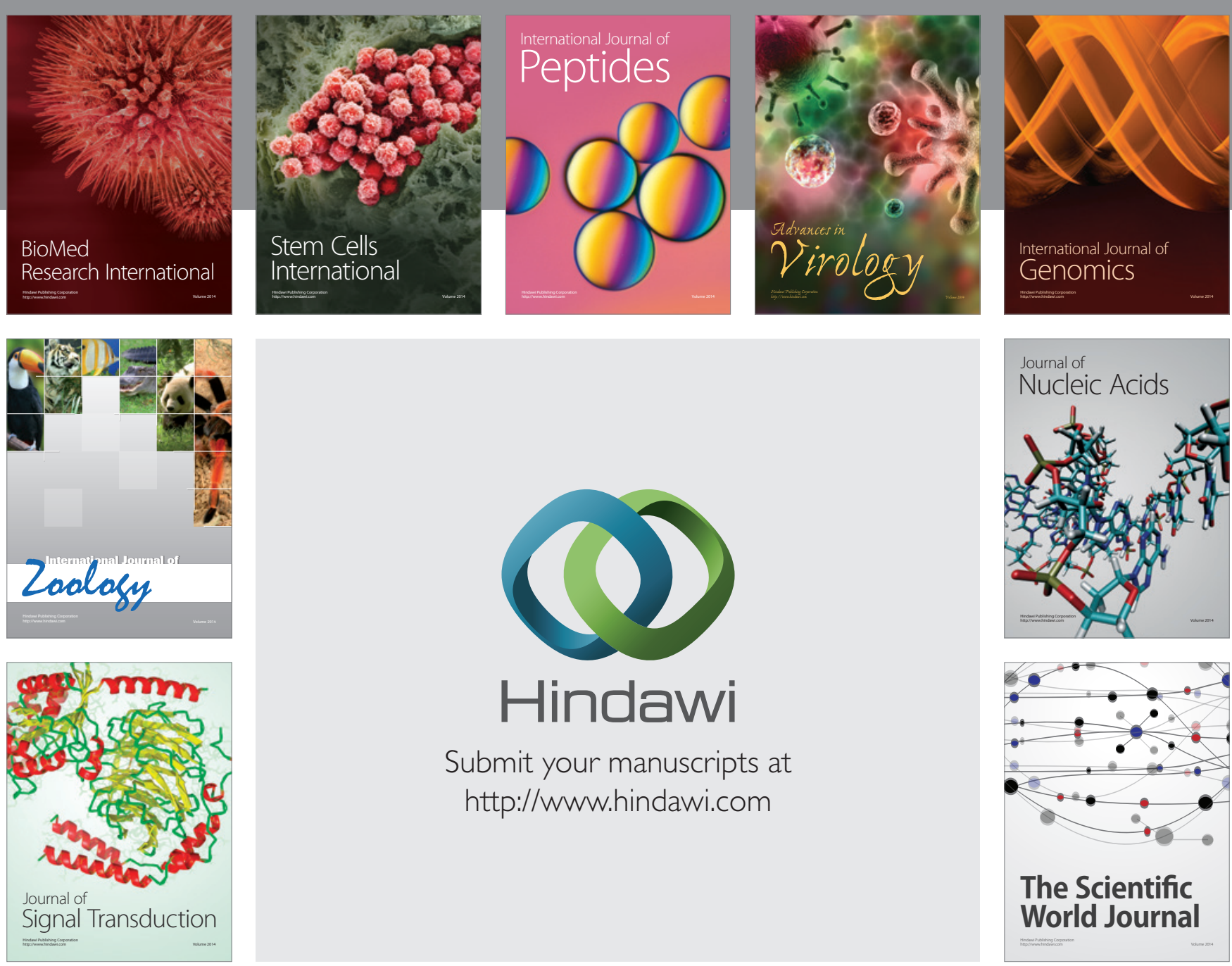

Submit your manuscripts at

http://www.hindawi.com
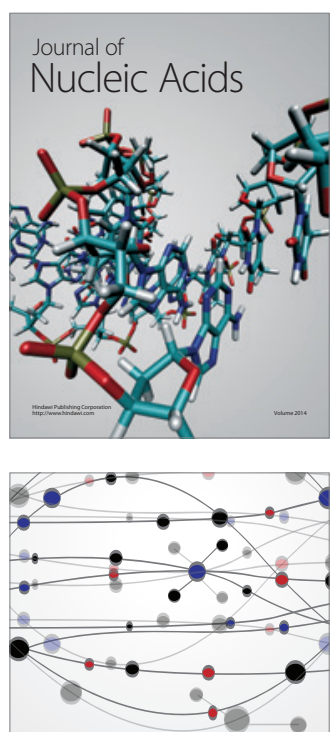

The Scientific World Journal
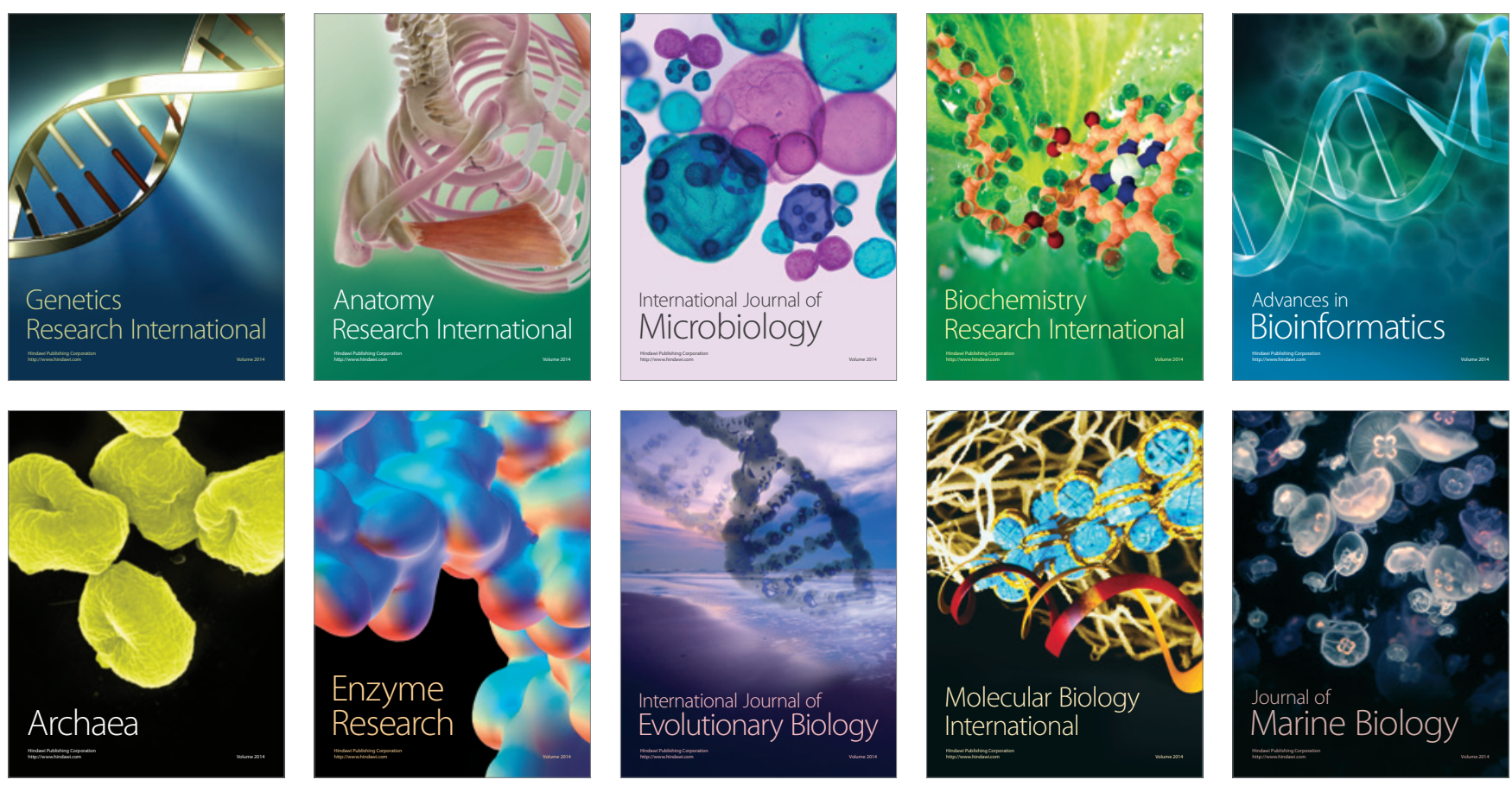